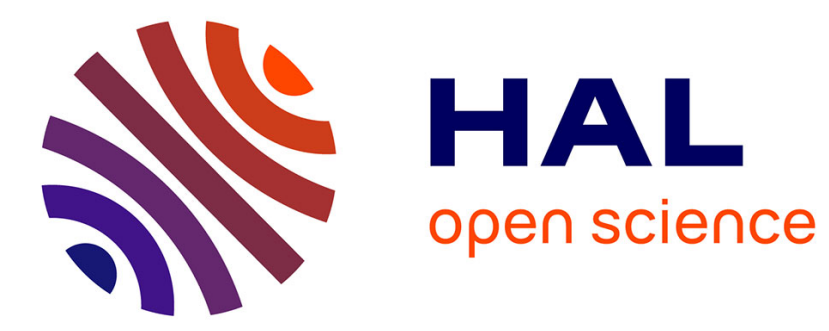

\title{
Crystal structure, optical and electrical properties of metal-halide compound [C7H16N2][ZnCl4]
}

Ines Ben Hadj Sadok, Fadhel Hajlaoui, Karim Karoui, Nathalie Audebrand, Thierry Roisnel, Nabil Zouari

\section{- To cite this version:}

Ines Ben Hadj Sadok, Fadhel Hajlaoui, Karim Karoui, Nathalie Audebrand, Thierry Roisnel, et al.. Crystal structure, optical and electrical properties of metal-halide compound [C7H16N2][ZnCl4]. Journal of Physics and Chemistry of Solids, 2019, 129, pp.71-80. 10.1016/j.jpcs.2018.12.039 . hal01996127

\section{HAL Id: hal-01996127 \\ https://hal.science/hal-01996127}

Submitted on 17 Apr 2019

HAL is a multi-disciplinary open access archive for the deposit and dissemination of scientific research documents, whether they are published or not. The documents may come from teaching and research institutions in France or abroad, or from public or private research centers.
L'archive ouverte pluridisciplinaire HAL, est destinée au dépôt et à la diffusion de documents scientifiques de niveau recherche, publiés ou non, émanant des établissements d'enseignement et de recherche français ou étrangers, des laboratoires publics ou privés. 


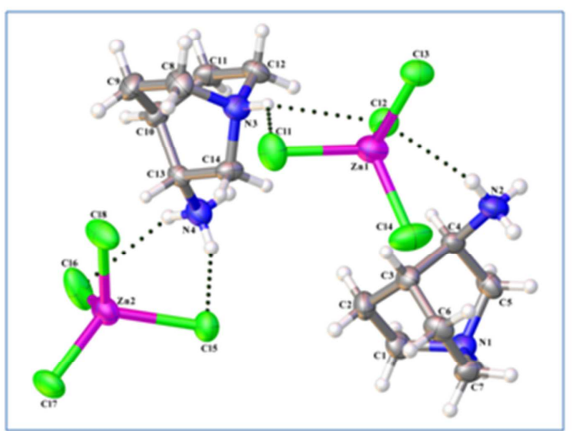

$\downarrow$

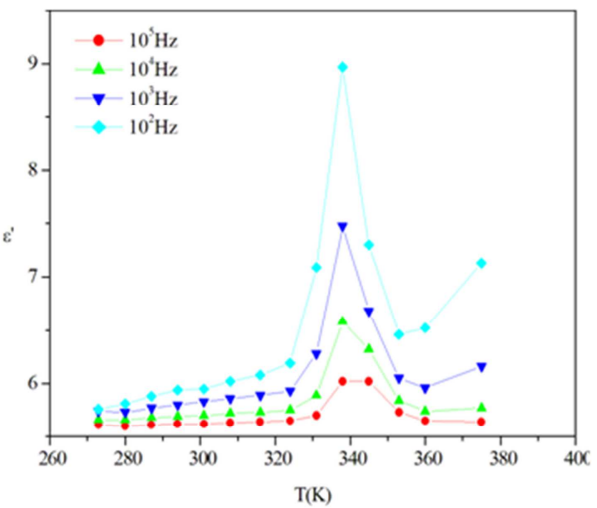

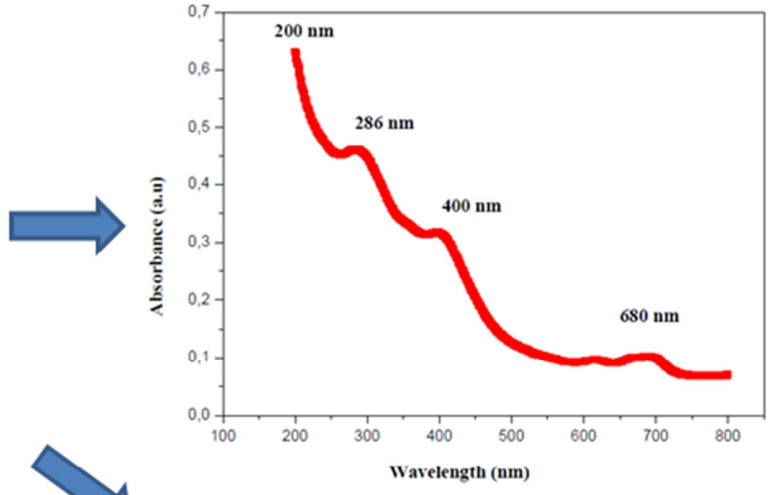

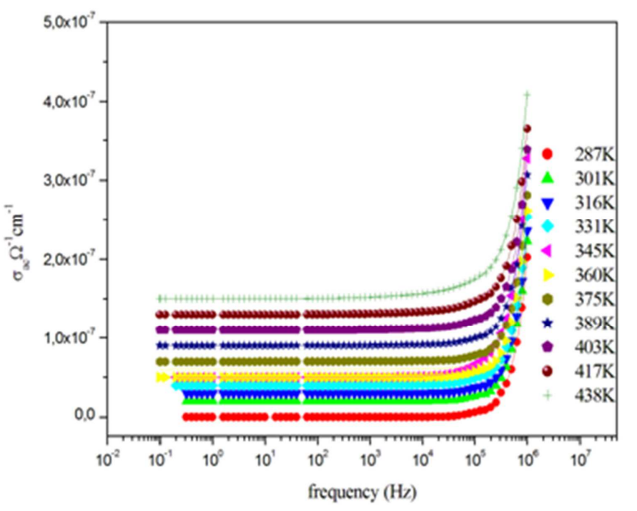




\title{
Crystal structure, optical and electrical properties of metal-halide compound $\left[\mathrm{C}_{7} \mathrm{H}_{16} \mathrm{~N}_{2}\right]\left[\mathrm{ZnCl}_{4}\right]$
}

\author{
Ines Ben Hadj Sadok ${ }^{\mathrm{a}}$, Fadhel Hajlaoui* ${ }^{\mathrm{a}}$, Karim Karoui ${ }^{\mathrm{b}}$, Nathalie Audebrand ${ }^{\mathrm{c}}$, Thierry Roisnel ${ }^{\mathrm{c}}$, \\ Nabil Zouari ${ }^{\mathrm{a}}$

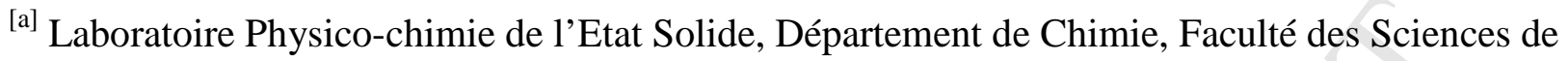 \\ Sfax, B.P. 1171, 3000 Sfax, Université de Sfax, Tunisia. \\ ${ }^{[b]}$ Laboratoire des caractérisations spectroscopiques et optique des matériaux, Faculté des Sciences \\ de Sfax-3000, Sfax, Tunisia \\ ${ }^{[c]}$ Univ Rennes, CNRS, ISCR (Institut des Sciences Chimiques de Rennes) - UMR 6226, F-35000 \\ Rennes, France
}

\author{
AUTHOR INFORMATION \\ * Corresponding author: Fadhel Hajlaoui. \\ * Email address: fadhelh83@yahoo.fr (F. Hajlaoui).
}

\begin{abstract}
A new organic-inorganic hybrid compound $\left[\mathrm{C}_{7} \mathrm{H}_{16} \mathrm{~N}_{2}\right]\left[\mathrm{ZnCl}_{4}\right]$ was synthesized by hydrothermal method and characterized by single-crystal X-ray diffraction, IR and Raman spectroscopy, optical absorption, differential scanning calorimetry and dielectric measurements. Single crystal diffraction results showed that $\left[\mathrm{C}_{7} \mathrm{H}_{16} \mathrm{~N}_{2}\right]\left[\mathrm{ZnCl}_{4}\right]$ crystallizes in the monoclinic system, space group $P 2_{1} / c$ at room temperature. In the molecular arrangement, the tetrachlorozincate anions are connected to organic cations through $\mathrm{N}-\mathrm{H} \cdots \mathrm{Cl}$ hydrogen bonds. The Raman and IR analyses confirm the presence of the organic groups and the anionic entities. UV-Visible absorption spectrum revealed the energy of the optical band gap. DSC measurements indicated that $\left[\mathrm{C}_{7} \mathrm{H}_{16} \mathrm{~N}_{2}\right]\left[\mathrm{ZnCl}_{4}\right]$ undergoes three sequential phase transitions at 287, 338 and $356 \mathrm{~K}$. The dielectric study proved the ferroelectric properties below the $338 \mathrm{~K}$ and indicates their classical character for this compound. The analysis of Nyquist plots revealed the contribution of the bulk mechanism and the grain boundaries.
\end{abstract}

Keywords: Hybrid material, Crystal structure, Optical absorption, Phase transitions, Ferroelectric properties, Conduction mechanism. 


\section{Introduction}

For the last decades, organic-inorganic metal halides have attracted intensive interest because of their technological aspects and potential applications in various areas such as magnetic [1-3], optoelectronics, memory devices [4-6], ferroelectrics and electrical [7-11] properties, etc. These types of materials have also received much attention owing their interesting molecular shapes. Moreover, the hybrid compounds have stimulated modern-day materials science research due to their innumerable characteristics such as non toxicity, flexibility, potential phase transition materials and lightness [12-14]. Recently, inorganic-organic phase transition materials with molecular formula $\mathrm{AMX}_{4}$ have been synthesized, in which $\mathrm{M}$ is a metal cation that coordinated by four $(\mathrm{X})$ anions to form an $\mathrm{AX}_{4}$ tetrahedron, and $\mathrm{A}$ is a organic cation. Especially, metal-halide compounds including 1,4-diazabicyclo [2.2.2] octane (dabco) and quinuclidine have made great progress [15-20]. For example, [quinuclidinium][ReO4][16]; $\left(\mathrm{H}_{2} \mathrm{dabco}-\mathrm{CH}_{2}-\mathrm{Cl}\right)\left[\mathrm{MCl}_{4}\right]$ [18] and $\left(\mathrm{H}_{2}\right.$ dabco- $\left.\mathrm{C}_{2} \mathrm{H}_{5}\right)\left[\mathrm{MCl}_{4}\right] \quad(\mathrm{M}=\mathrm{Co}, \mathrm{Zn})$ [20] contain an independent organic cations and a discrete $\left[\mathrm{MX}_{4}\right]^{\mathrm{n}-}(\mathrm{M}=\mathrm{Co}, \mathrm{Zn})$ anions. Quinuclidinium perrhenate (I) compound, exhibits ferroelectricity above room temperature and undergoes a phase transition to a plastic crystal phase at a higher temperature [16]. Eventually, these hybrid compounds containing the quinuclidinium or their derivatives can be considered as potential switchable dielectric materials which lead to the paraferroelectric phase transitions. In this context, 3-aminoquinuclidine as the derivative of dabco, was protonated and combined with metal halides, forming a new hybrid compound $\left[\mathrm{C}_{7} \mathrm{H}_{16} \mathrm{~N}_{2}\right]\left[\mathrm{ZnCl}_{4}\right]$. This synthesized compound was characterized by single crystal X-ray diffraction, optical studies, differential scanning calorimetric analysis, electric and dielectric measurements as a function of temperature in order to confirm its purity, to investigate the ferroelectric properties and to study the optical and electrical properties.

\section{Experimental section}

\subsection{Materials}

Zinc (II) chloride $\left(\mathrm{ZnCl}_{2}\right)$, hydrochloric acid $(\mathrm{HCl} ; 37 \%)$, 3-aminoquinuclidine dihydrochloride $\left(\mathrm{C}_{7} \mathrm{H}_{14} \mathrm{~N}_{2} \cdot 2 \mathrm{HCl}\right)$ were purchased from Sigma-Aldrich and used without further purification.

\subsection{Synthesis}

The synthesis of 3-aminoquinuclidinediium tetrachlorozincate (II) complex was carried out in home-built Teflon-lined stainless steel pressure bombs of $120 \mathrm{~mL}$ maximum capacity. $1 \mathrm{mmol}$ of $\mathrm{ZnCl}_{2}$ and $2 \mathrm{mmol}$ of 3-aminoquinuclidine dihydrochloride were dissolved together in $20 \mathrm{~mL}$ of deionized water and hydrochloric acid $(\mathrm{pH} \approx 3)$. The mixture was placed in a Teflon-lined autoclave that was then sealed and heated to $110^{\circ} \mathrm{C}$ for 2 days. It was then allowed to cool to room temperature in a cold water bath. Autoclaves were opened in air, and products were recovered through filtration. White stick-shaped crystals with suitable dimensions for crystallographic study 
were recovered. The crystals were washed several times with distilled water and dried in open air. Reaction yields ranged between $60-70 \%$ based on $\mathrm{Zn}$. No additional reaction products other than that described below, crystalline or amorphous were observed. Elem. microanal. Obsd for $\left[\mathrm{C}_{7} \mathrm{H}_{16} \mathrm{~N}_{2}\right]\left[\mathrm{ZnCl}_{4}\right]$ (calcd): C, 26.28 (25.04); H, 4.17 (4.77); N, 8.14 (8.34).

\subsection{Single-crystal data collection and structure determination}

Suitable crystals were mounted on an APEX II AXS-Bruker area detector 4-circles diffractometer. Intensity data sets were collected using Mo K $\alpha$ radiation $(\lambda=0.71073 \AA)$ through the Bruker AXS APEX2 Software Suite [21]. Frame integration and data reduction were carried out with the program SAINT [22]. The program SADABS [23] was then employed for multiscan-type absorption corrections. The crystal structure was solved in the monoclinic symmetry, space group $P 2_{1} / c$, according to the automated search for space group available in Wingx [24]. Zinc and chloride atoms were located using the direct methods with the program SIR-2014 [25]. C and N atoms from the amine were found from successive difference Fourier calculations using SHELXL-2014 [26]. Their positions were validated from geometrical considerations as well as from the examination of possible hydrogen bonds. $\mathrm{H}$ atoms were positioned geometrically and allowed to ride on their parent atoms, with $\mathrm{C}-\mathrm{H}=0.97 \AA$ and $\mathrm{N}-\mathrm{H}=0.89 \AA$. When the nitrogen is the protonated tertiary one, N(3) and N(1), the distance was fixed to $0.98 \AA$. Structure drawings have been made with Olex2 [27] program. Crystallographic data are given in Table 1.

\subsection{Spectroscopies studies}

The Raman spectra were excited by the $514.5 \mathrm{~nm}$ wavelength radiation of an $\mathrm{Ar} / \mathrm{Kr}$ laser, and collected with a T64000 Raman spectrometer in the $180-3500 \mathrm{~cm}^{-1}$ range. The spectrum was collected in all polarizations, but only the obtained in the $\mathrm{Z}(\mathrm{XX}) \mathrm{Z}$ polarization is presented with regard to their best signal-to-noise ratio.

IR absorption spectrum of the crystallized powders in KBr was recorded on a Perkin- Elmer FT-IR 1000 spectrometer in the $400-4000 \mathrm{~cm}^{-1}$ range.

Optical properties are measured at room temperature using a Shimadzu-type 3101PC UV spectrophotometer that has a dual-beam monochromator, covers a spectrum from $200 \mathrm{~nm}$ to 2400 $\mathrm{nm}$ and uses two sources: (i) Xenon lamp for the UV-Visible domain, (ii) Halogen lamp for the infrared range. This technique makes it possible to determine the absorbance (A) and the reflectance (R). The optical absorption spectrum of the $\left[\mathrm{C}_{7} \mathrm{H}_{16} \mathrm{~N}_{2}\right]\left[\mathrm{ZnCl}_{4}\right]$ compound was recorded at room temperature in powder used in the form of films.

\subsection{Thermal measurements}

TGA measurements were performed on raw powders with a TGA 'SETSYS Evolution' under a $\mathrm{N}_{2}$ atmosphere of $\left[\mathrm{C}_{7} \mathrm{H}_{16} \mathrm{~N}_{2}\right]\left[\mathrm{ZnCl}_{4}\right]$. The thermogram was collected on $12.5 \mathrm{mg}$ sample in the RT$650 \mathrm{~K}$ range (heating rate of $5^{\circ} \mathrm{C} / \mathrm{min}$ ). 
DSC measurements were recorded on raw powders with NETZCSCH DSC 200 F3 instrument (Pt crucibles, $\mathrm{Al}_{2} \mathrm{O}_{3}$ as a reference) under nitrogen atmosphere. The thermograms were collected on $8 \mathrm{mg}$ sample in the temperature range from 258 to $423 \mathrm{~K}$ with heating and cooling rate of $5{ }^{\circ} \mathrm{C} / \mathrm{min}$.

\subsection{Impedance spectroscopy}

The electrical measurements of the real and imaginary components of the impedance parameters (Z' and Z') were measured on pellet disks of about $8 \mathrm{~mm}$ in diameter and $1.2 \mathrm{~mm}$ in thickness in the frequency range of $1-10^{6} \mathrm{~Hz}$, with the SOLARTRON SI 1260 impedance coupled to a dielectric interface 1296 in the temperature range of $280-480 \mathrm{~K}$.

\section{Results and discussion}

\subsection{Crystal Structure}

$\left[\mathrm{C}_{7} \mathrm{H}_{16} \mathrm{~N}_{2}\right]\left[\mathrm{ZnCl}_{4}\right]$. The structure of the 3-aminoquinuclidinediium tetrachlorozincate (II) was determined by X-ray diffraction analysis. At room temperature, data were consistent with the $P 2{ }_{1} / c$ space group with unit cell parameters $a=21.3562(13) \AA, b=7.4060(4) \AA, c=17.3938(12) \AA, \beta=$ $105.777(3)^{\circ}$ and $\mathrm{Z}=4$. The asymmetric unit of the structure, as shown in Figure 1 , was found to contain two types of $\left[\mathrm{ZnCl}_{4}\right]^{2-}$ tetrahedra and two symmetrically independent 3-aminoquinuclidinediium cations, $\left[\mathrm{C}_{7} \mathrm{H}_{16} \mathrm{~N}_{2}\right]^{2+}$. The organic species interact with the inorganic entities via $\mathrm{N}-\mathrm{H}^{\cdots}{ }^{\cdots} \mathrm{Cl}$ hydrogen bonds. Selected bond lengths and angles are given in Table 2. The molecular arrangement of $\left[\mathrm{C}_{7} \mathrm{H}_{16} \mathrm{~N}_{2}\right]\left[\mathrm{ZnCl}_{4}\right]$ is shown in Figure 2. The crystal structure can be described as alternating of 3-aminoquinuclidinediium cations and layers of anions, the latter are built up of tetrahedra of tetrachlorozincate $\mathrm{ZnCl}_{4}$ alternated with different organic cations forming infinite zigzag chains that run parallel to the $a$-axis. The anionic sub lattice is constructed of two independent distorted tetrahedra $\left[\mathrm{Zn}(1) \mathrm{Cl}_{4}\right]$ and $\left[\mathrm{Zn}(2) \mathrm{Cl}_{4}\right]$. Within anionic layers (Figure 3), the distances between $\mathrm{Zn}$ atoms are $7.51 \AA$, $6.64 \AA$, and $5.92 \AA$, respectively. The $\mathrm{Zn}-\mathrm{Cl}$ bonds are in the range $2.2317(9)-2.3056(9) \AA$. The $\mathrm{Cl}-\mathrm{Zn}-\mathrm{Cl}$ angle values vary from 101.29 (4) to $119.00(4)^{\circ}$ with a mean of $109.48(2)^{\circ}$. The geometrical features of $\mathrm{ZnCl}_{4}$ entities agree well with those reported by other $\mathrm{Zn}$ (II) salts containing isolated tetrahedra [28-29]. Organic cations neutralize the negative charge of the anionic part. The $\mathrm{C}-\mathrm{C}$ bond lengths vary from $1.517(5)$ to $1.535(5) \AA$ and the $\mathrm{C}-\mathrm{C}-\mathrm{C}$ angle values are in the range 106.2(3)-111.0 (3) $)^{\circ}$. The selected bond lengths and bond angles within the cationic part indicating that the N-C, C-C distances and the N-C-C, C-N-C, C-C-C angles are comparable with those observed in other similar hybrid metal-halides with the same organic cation [30-31]. The structure is stabilized by intermolecular hydrogen-bonding interactions leading to layers that are parallel to $\mathrm{b}$ and c axes. These layers are stabilized through extensive N$\mathrm{H} \cdots \mathrm{Cl}$ hydrogen bonding between the inorganic and organic moieties. Indeed, the $\mathrm{N}-\mathrm{H}^{\cdots} \mathrm{Cl}$ bonds

vary from 3.157(3) to 3.583(3) $\AA$. These interactions play a significant role in the formation of 
three-dimensional architectures and stabilizing the supramolecular structure. The hydrogen bond parameters are given in Table 3.

\subsection{Vibrational frequencies}

Raman and IR complementary techniques are used to identify the presence of all molecular groups for the synthesized compound. These spectra are recorded in Figure 4 (a) and (b). The Raman spectrum shows three frequency regions: the first under $350 \mathrm{~cm}^{-1}$ corresponding to the $\mathrm{Zn}-\mathrm{Cl}$ vibration modes and indicates the presence of the $\mathrm{ZnCl}_{4}{ }^{2-}$ anion, the second region between 350 and $1600 \mathrm{~cm}^{-1}$ corresponds to the $\mathrm{NC}_{4}, \mathrm{CH}_{2}, \mathrm{NH}_{3}$ and $\mathrm{C}-\mathrm{N}-\mathrm{H}$ vibrations modes, the third region above the $2500 \mathrm{~cm}^{-1}$ indicate the $\mathrm{C}-\mathrm{H}$ stretching vibration. All vibrations modes of the organic cation above $350 \mathrm{~cm}^{-1}$ appears with a small difference in frequency in the IR spectrum (Table 4). This result confirms the presence of the inorganic and organic entities proved by the X-ray diffraction analysis.

\subsection{Optical energy gap analysis of $\left[\mathrm{C}_{7} \mathrm{H}_{16} \mathrm{~N}_{2}\right]\left[\mathrm{ZnCl}_{4}\right]$}

Figure 5 (A) showed the UV-vis spectrum of $\left[\mathrm{C}_{7} \mathrm{H}_{16} \mathrm{~N}_{2}\right]\left[\mathrm{ZnCl}_{4}\right]$ at room temperature with four distinct absorption peaks at 200, 286, 400, 615 and $686 \mathrm{~nm}$ which is very similar to those found in the $\left(\mathrm{C}_{5} \mathrm{H}_{7} \mathrm{~N}_{2}\right)_{2} \mathrm{CuCl}_{4} \mathrm{H}_{2} \mathrm{O}$ and $\left(\mathrm{C}_{8} \mathrm{H}_{10} \mathrm{NO}\right)_{2} \mathrm{CdCl}_{4}$ compounds [32-34]. The lowest energy absorption peak at $200 \mathrm{~nm}$ is due to band gap absorption and it is assigned to the excitation of free electronhole pairs within the $\left[\mathrm{ZnCl}_{4}\right]^{2-}$ inorganic anion. It is due mainly to the absorption between $\mathrm{Cl}(3 \mathrm{p})$ and $\mathrm{Zn}(4 \mathrm{~s})$. In fact an electron is excited from the valence band (VB) to a permit level in the gap leaving a hole in the (VB). The other peaks can be assigned for transitions between energetic levels in the same bands or from (VB) band to conduction band (CB) [34]. The absorption coefficient $(\alpha)$ $\left(\mathrm{cm}^{-1}\right)$ is deduced from the absorbance by the following relation:

$$
\alpha=2.303 A / d \quad(1)
$$

Where $d(\mathrm{~cm})$ and $A$ represent the thickness and the absorbance respectively.

This coefficient is used to determinate the optical band gap value using Tauc's expression for direct and indirect band transition [35]:

$$
(\alpha h v)^{1 / n}=B\left(h v-E_{g}\right)
$$

where $B$ is a constant, $E_{g}$ is optical Band gap, $n=1 / 2$ for direct allowed transition and $n=2$ for indirect allowed transition.

The dependence of $(\alpha h v)^{2}$ and $(\alpha h v)^{1 / 2}$ on the photon energy are shown in Figure 5 (B) and (C). The values of the optical band gap $E g$ are obtained by extrapolating the linear part of the curve to intersect the $\mathrm{X}$-axis [36]. The allowed direct and indirect optical band gaps of the samples are 5.27 
and $4.90 \mathrm{eV}$. These values are close to the similar compounds such as $\left[\left(\mathrm{CH}_{3}\right)_{3} \mathrm{NH}\right] \mathrm{CdCl}_{3}$ and $\left[\mathrm{N}\left(\mathrm{CH}_{3}\right)_{3} \mathrm{H}\right] \mathrm{CoCl}_{3} \cdot 2 \mathrm{H}_{2} \mathrm{O}$ [37], $\left[\mathrm{C}_{2} \mathrm{H}_{5} \mathrm{NH}_{3}\right]_{2} \mathrm{ZnCl}_{4}$ [29] and can indicate the insulating or semiconductor nature for the titled compound [29, 37].

The behavior of the $E_{U}$ can describe the degree of disorder and the defects of the structural connection of this material $[38,39]$. The Urbach energy $\left(E_{u}\right)$ tailing is used based on the equation (3):

$$
\ln (\alpha)=\ln \left(\alpha_{0}\right)+\mathrm{h} v / \mathrm{E}_{\mathrm{u}}
$$

The inverse of the slope of the straight line $(\ln (\alpha))$ versus $(h v)$ deduced from the Figure 5 (D), leads to the calculated value of $E_{u}$ which equals to $0.21 \mathrm{eV}$. This weak value of $\mathrm{E}_{\mathrm{U}}$ confirms the structural result and indicates that this compound is ordered.

\subsection{Thermal behavior}

The TG curve of the compound $\left[\mathrm{C}_{7} \mathrm{H}_{16} \mathrm{~N}_{2}\right]\left[\mathrm{ZnCl}_{4}\right]$, carried out with a heating rate of $5^{\circ} \mathrm{C} / \mathrm{min}$ from 298 to 650K, is depicted in Figure. S1 (See Supporting Information). The TG analyses indicates that $\left[\mathrm{C}_{7} \mathrm{H}_{16} \mathrm{~N}_{2}\right]\left[\mathrm{ZnCl}_{4}\right]$ is stable unto $450 \mathrm{~K}$.

DSC measurements were recorded on heating and cooling (Figure 6) in the 258 to $423 \mathrm{~K}$ temperature ranges in order to determinate the phase transitions. This study shows three anomalies at 287,388 and $356 \mathrm{~K}$, that can lead to interesting physical properties as it was reported in earlier studies for similar hybrid metal halide salts [7-9, 20].

\subsection{Electrical properties and phase transitions}

\subsubsection{Ferroelectric properties}

The variation of the real and imaginary part of the relative permittivity as a function of the temperature at various frequencies (Figure 7 (a) and (b)). This temperature dependence of $\varepsilon^{\prime}$ and $\varepsilon^{\prime \prime}$ displays a sharp peak at $\mathrm{T}_{\mathrm{c}}=338 \mathrm{~K}$, characteristic of ferroelectric transitions which is related to the peak observed in the DSC curve. The ferroelectric-paraelectric temperature transition is independent with frequency which proves that this compound is a classic ferroelectric [40].

For the classical ferroelectric materials, the order of Tc transition is determined based in the CurieWeiss law:

$$
\varepsilon^{l}=\frac{\mathrm{C}}{\mathrm{T}-\mathrm{T}_{0}}(\mathbf{4})
$$

where $\mathrm{C}$ is the Curie-Weiss constant and $\mathrm{T}_{0}(\mathrm{~K})$ is the Curie-Weiss temperature. 
The Curie-Weiss plot $1 / \varepsilon^{\prime}$ versus temperature gives a straight line with the $\mathrm{X}$-axis intercept at $\mathrm{T}_{0}$. This temperature equal to $326 \mathrm{~K}$ (Figure 7 (c)) is different of $T_{c}$ indicating that this transition is of the first order [41].

\subsubsection{Nyquist diagram and equivalent circuit}

Electrical measurements as function of the temperature were mode to study the properties of this material such as the conductivity and to characterize the transition phases detected by the calorimetric study. Nyquist diagram spectra of $\left[\mathrm{C}_{7} \mathrm{H}_{16} \mathrm{~N}_{2}\right]\left[\mathrm{ZnCl}_{4}\right]$ at different temperatures are shown in the Figure 8 (A) and (C). The radius of the semi-circles decreasing with increasing temperature indicates that the conductivity is thermally activated. The some depression observed in these spectra indicates a non-Debye type relaxation [40]. Two regions can be described in the Nyquist diagram spectra: (i) the first one between $280 \mathrm{~K}$ and $382 \mathrm{~K}$ consists in a single semi-circular due to the consequence of the grain conduction in this material and modeled by a parallel R//CPE circuit where CPE is the fractal capacitance; (ii) the second one between $389 \mathrm{~K}$ and $480 \mathrm{~K}$ shows double semicircular arcs due to the grain (in the high frequency domain) and grain boundary (in the low frequency domain) conduction and modeled by a combination series of parallel R//CPE and $\mathrm{R} / / \mathrm{C} / / \mathrm{CPE}$. The good conformity of the calculated lines and the experimental data (Figure 8 (B) and (D)) indicates that the suggested equivalent circuit describes well the behavior of this material. The extracted resistance $(\mathrm{R})$ values by the Nyquist diagram simulation are used to calculate the grain conduction based on the following equation:

$$
\sigma_{g}=\frac{\theta}{R S}
$$

Where e $(\mathrm{cm})$ and $S\left(\mathrm{~cm}^{2}\right)$ are the thickness and surface of a pellet, $\sigma_{\mathrm{g}}\left(\Omega^{-1} \mathrm{~cm}^{-1}\right)$ is the conductivity of grain.

The variation of $\operatorname{Ln}\left(\sigma_{\mathrm{g}}\right)$ versus temperature shown in Figure 9 is described by the Arrhenius law. Furthermore, a change of the slope curve near each transition is observed in the calorimetric study. This can confirm these transitions and prove the dependence of the electrical and structural properties of this compound. The calculated activation energies of the conduction process for all phase are $\mathrm{E}_{\mathrm{al}}=0.14 \mathrm{eV}, \mathrm{E}_{\mathrm{aII}}=1.42 \mathrm{eV}, \mathrm{E}_{\mathrm{aIII}}=0.42 \mathrm{eV}$ and $\mathrm{E}_{\mathrm{aIV}}=0.75 \mathrm{eV}$.

\subsubsection{Ac conductivity and conduction mechanism}

The frequency dependence of the electrical conductivity at various temperatures (Figure 10) shows weak temperature dependence and a strong frequency dependence effects. Two regions appear in these spectra: the first at low frequency with a plateau representing the total conductivity, the 
second at high frequency where the grain contribution relaxes in the dispersion region. This behavior suggests that electrical conductivity is described by the Jonscher's power law [42-43]:

$$
\sigma_{a e}=\sigma_{d e}+A \omega^{s}
$$

where $\sigma_{\mathrm{ac}}$ and $\sigma_{\mathrm{dc}}\left(\Omega^{-1} \mathrm{~cm}^{-1}\right)$ are the AC and DC conductivity, respectively, $\mathrm{A}$ is a constant and $\mathrm{S}$ is the frequency exponent in the range of $0<S<1$.

The simulated spectra of AC conductivity by the equation 6 allow determining the DC conductivity and the exponent (S) for all the temperatures. Figure 11 shows the variation of the DC conductivity as function of the temperature and confirmed the changes observed near the phase transitions of this compound. All the behaviors are described by the Arrhenius low and the activation energies are: $\mathrm{Ea}_{\mathrm{l}}=0.15 \mathrm{eV}, \mathrm{E}_{\mathrm{aII}}=0.87 \mathrm{eV}, \mathrm{E}_{\mathrm{aIII}}=0.42 \mathrm{eV}$ and $\mathrm{E}_{\mathrm{aIV}}=0.60 \mathrm{eV}$.

The behavior of the exponent (S) (Figure 12) as a function of the temperature can be used to determine the origin of the conduction mechanism. Different theoretical models related to the variation of the exponent (S) such as the quantum mechanical tunneling (QMT) model [44], the non-overlapping small Polarons (NSPT) model [45], the overlapping-large polaron tunneling (OLPT) model [46] and the correlated barrier hopping (CBH) model [47] have been reported. Based on the variation of the exponent (S) (Figure 12), the first phase is described by NSPT model where the exponent $S$ increase with increasing temperature, in the second phase the exponent $S$ decreases with increasing temperature up to a minimum and then increases suggesting that OLPT model is suitable for the conduction, in the third and fourth phases the exponent $\mathrm{S}$ decreases with increasing temperature which indicates that the $\mathrm{CBH}$ model described the conduction. To confirm these attributions, we used the equations of each mechanism based on Elliot's theory [48] and we performed a fitting of the variation $\sigma_{\mathrm{ac}}$ as a function of the temperature (Figure 13):

\section{- NSPT model}

The exponent $S$ increases as $T$ increases and given by [48]:

$$
S=1-\frac{4}{\ln \left(\frac{1}{\omega \tau_{0}}\right)-\frac{W_{H}}{K T}}
$$

The $\sigma_{\mathrm{ac}}$ and the exponent $\mathrm{S}$ are given by Long [49] as:

$$
\sigma(\omega)=(\pi e)^{2} k T \alpha^{-1} \omega\left[N_{\left(E_{F}\right)} T\right]^{2} \frac{R_{\omega}{ }^{4}}{12}
$$

where $\omega_{\mathrm{H}}$ is energy of polaron hopping, $\alpha^{-1}\left(\mathrm{~A}^{\circ}\right)$ is the spatial extension of the polaron, $\mathrm{R}_{\omega}$ is the tunneling distance, $\tau_{0}$ represents the characteristic relaxations time its value is in the 
order of an atom vibrational period $\left(1 \mathrm{E}^{-13} \mathrm{~S}\right)$. and $\mathrm{N}\left(\mathrm{E}_{\mathrm{F}}\right)$ is the density of states near the Fermi level.

\section{- OLPT model}

The ac conductivity expected from a model in which tunneling of polarons is still the dominant mechanism, but where an appreciable overlap of the polaron distortion clouds occurs.

The ac conductivity was given by [49] as:

$$
\sigma_{a c}(\omega)=\frac{\pi^{4}}{12} e^{2}(k T)^{2} N^{2}\left(E_{F}\right) \frac{\omega R_{\omega}^{4}}{2 \alpha k T+\frac{\omega_{H 0} r_{p}}{R_{\omega}^{2}}}
$$

where $r_{p}$ is the polaron radius

\section{- CBH model}

In this model, Long [49] has calculated the ac conductivity to be:

$$
\sigma_{a c}=\frac{n \pi^{2} N N_{p} \varepsilon^{\prime} \omega R_{\omega}{ }^{61}}{24}
$$

Where $\mathrm{n}$ is the number of polaron for the hopping process, $\mathrm{NN}_{\mathrm{p}}$ is the states density and $\varepsilon^{\prime}$ is the dielectric constant.

As indicated in this figure 13 , we have come to realize good adjustments of experimental curves, the extracted parameters by this adjustment are listed in the table 5 . We notice that an increase in the frequency causes an increase in the states density localizes.

\section{Conclusion}

In conclusion, we have prepared a novel hybrid metal-halide material $\left[\mathrm{C}_{7} \mathrm{H}_{16} \mathrm{~N}_{2}\right]\left[\mathrm{ZnCl}_{4}\right]$, which exhibits a three sequential phase transitions at about 287, 338 and $356 \mathrm{~K}$, being confirmed by the DSC measurements together with dielectric anomalies. The compound crystallizes in the monoclinic $P 2_{1} / c$ space group at room temperature having isolated $\left[\mathrm{ZnCl}_{4}\right]^{2-}$ anions and 3aminoquinuclidinediium cations. They are connected each other through $\mathrm{N}-\mathrm{H}^{\cdots} \mathrm{Cl}$ hydrogen bonds 
to form cation-anion-cation molecular units. All vibrational modes of molecular group are confirmed by the IR and Raman techniques. A first order type phase transition observed at $338 \mathrm{~K}$ and confirmed by Curie-Weiss law, proves that this compound is a classic ferroelectric. The optical properties at the absorption edge of $\left[\mathrm{C}_{7} \mathrm{H}_{16} \mathrm{~N}_{2}\right]\left[\mathrm{ZnCl}_{4}\right]$ showed four distinct peaks at 200, 286, 400 and $680 \mathrm{~nm}$, respectively. The values of the band gap energies direct and indirect are 5.27 and 4.90 $\mathrm{eV}$. The equivalent circuit was determined and the impedance spectra have revealed the contributions of grain and grain boundary in the conduction for this material. The conduction mechanisms have been discussed in each phase based on Elliott's theory.

\section{Appendix}

Supplementary crystallographic data for this article in CIF format are available as Electronic Supplementary Publication from Cambridge Crystallographic Data Centre (CCDC 1553738). This data can be obtained free of charge via http://www.ccdc.cam.ac.uk/conts/retrieving.html, or from the Cambridge Crystallographic Data Centre, 12 Union Road, Cambridge CB2 1EZ, UK (Fax: (international): +44 1223/336033; e-mail: deposit@ccdc.cam.ac.uk).

\section{Acknowledgments}

The authors would gratefully acknowledge the help of the Ministry of Higher Education and Scientific Research, Tunisia.

\section{Conflicts of interest}

There are no conflicts to declare.

\section{References}

[1] A. Piecha-Bisiorek, A. Bieńko, R. Jakubas, R. Boča, M. Weselski, V. Kinzhybalo, A. Pietraszko, M. Wojciechowska, W. Medycki, D. Kruk, J. Phys. Chem. A. 120 (2016) 2014.

[2] B. Kundys, A. Lappas, M. Viret, V. Kapustianyk, V. Rudyk, S. Semak, C. Simon, I. Bakaimi, Phys. Rev. B 81 (2010) 224434.

[3] A. O. Polyakov, A. H. Arkenbout, J. Baas, G. R. Blake, A. Meetsma, A. Caretta, P. H. M. van Loosdrecht, T. T. M. Palstra, Chem. Mater., 24 (1) (2012) 133.

[4] (a) X.-H. Lv, W.-Q. Liao, P.-F. Li, Z.-X. Wang, C.-Y. Mao, Y. Zhang, J. Mater. Chem. C, 4 (2016) 1881; (b) W.-Q. Liao, H.- Y. Ye, Y. Zhang, R. G. Xiong, Dalton Trans., 44 (2015) 10614.

[5] (a) G. Xing, N. Mathews, S. S. Lim, N. Yantara, X. Liu, D. Sabba, M. Gratzel, S. Mhaisalkar, T. C. Sum, Nat. Mater., 13 (2014) 476; (b) H. Cho, S.-H. Jeong, M.-H. Park, Y.-H. Kim, C. Wolf, 
C.-L. Lee, J.-H. Heo, A. Sadhanala, N. Myoung, S. Yoo, S. H. Im, R. H. Friend, T.-W. Lee, Science, 350 (2015) 1222.

[6] M. Liu, M. B. Johnsto, H. J. Snaith, Nature, 501 (2013) 395.

[7] T. Khan, M. A. Asghar, Z. Sun, A. Zeb, C. Ji, J. Luo, J. Mater. Chem. C, 5 (2017) 2865.

[8] Y. Zhang, W. Qiang, L. D. W. Fu, H.Y. Ye, Z.N. Chen, R.G. Xiong, J. Am. Chem. Soc., 137 (2015) 4928.

[9] M. A. Asghar, S. Zhang, T. Khan, Z. Sun, A. Zeb, C. Ji, L. Li, S. Zhao, J. Luo, J. Mater. Chem. C, 4 (2016) 7537.

[10] W. Zhang, H.-Y. Ye, H.-L. Cai, J.-Z. Ge, R.-G. Xiong, S. D. Huang, J. Am. Chem. Soc., 132 (2010) 7300 .

[11] H.-Y. Ye, Q. Zhou, X. Niu, W.-Q. Liao, D.-W. Fu, Y. Zhang, Y.-M. You, J. Wang, Z.-N.

Chen, R.-G. Xiong, J. Am. Chem. Soc., 137 (2015) 13148.

[12] K. Hasebe, H. Mashiyama, S. Tanisaki, J. Phys. Soc. Japan. 49 (1980) 1633.

[13] J. Han, S. Nishihara, K. Inoue, M. Kurmoo, Inorg. Chem. 54 (2015) 2866.

[14] A. Caretta, R. Miranti, R.W.A. Havenith, E. Rampi, M.C. Donker, G.R. Blake, M. Montagnese, A.O. Polyakov, R. Broer, T.T.M. Palstra, P.H.M. van Loosdrecht, Phys. Rev. B. 89 (2014) 24301.

[15] L. Z. Chen, Q. Ji, X. G. Wang, Q. J. Pan, X. X. Cao, CrystEngComm, 19 (2017) 5907.

[16] J. Harada, T. Shimojo, H. Oyamaguchi, H. Hasegawa, Y. Takahashi, K. Satomi, Y. Suzuki, J. Kawamata, T. Inabe, Nat. Chem. 8 (2016) 946.

[17] H. L. Cai, W. Zhang, J. Z. Ge, Y. Zhang, K. Awaga, T. Nakamura, R. G. Xiong, Phys. Rev. Lett., 107 (2011) 147601.

[18] C-H. Chen, G.-C. Xu, CrystEngComm., 18 (2016) 550.

[19] C. A. Bremner, W. T. Harrison, Acta Crystallogr., Sect. E, 59 (2003) 425.

[20] Q. Ji, L. Li, S. Deng, X. Cao, L. Chen, Dalton Trans., 47 (2018) 5630.

[21] APEX2 program suite, 11-0, Bruker AXS Inc. Madison, Wisconsin, USA (2014).

[22] G.M. Sheldrick, SAINT, Version 8.37A, Bruker AXS Inc., Madison, Wisconsin, USA (2013).

[23] G.M. Sheldrick SADABS version, Bruker AXS Inc., Madison, Wisconsin, USA (2014).

[24] L. J. Farrugia. J. Appl. Cystallogr., 32 (1999) 837.

[25] A. Altomare, M. C. Burla, M. Camalli, G. L. Cascarano, C. Giacovazzo, A. Guagliardi, A. G. G. Moliterni, G. Polidori, R. J. Spagna, Appl. Crystallogr., 32 (2014) 115.

[26] G.M. Sheldrick. SHELXL-2014/1, Program for Crystal Structure Refinement University of Göttingen: Germany (2014).

[27] O.V. Dolomanov, L.J. Bourhis, R.J. Gildea, J.A.K. Howard, H. Puschmann, Olex2 program. J. Appl. Cryst., 42 (2009) 339. 
[28] N. Chihaoui, B. Hamdi, R. Zouari, J. Mol. Struct., 1147 (2017) 48.

[29] C. Ben Mohamed, K. Karoui, M. Tabellout, A. Ben Rhaiem. J. Alloys Compd., 688 (2016) 407.

[30] D. Boenigk, D. J. Mootz, J. Am. Chem. Soc., 110 (1988) 2135.

[31] K. Azouzi, B. Hamdi, R. Zouari, A. Ben Salah, Ionics, 22 (2016) 1669.

[32] A. Kessentini, M. Belhouchet, J. J. Suñol, Y. Abid, T. Mhiri, J. Lumin., 149 (2014) 341.

[33] W. Wang, X. Chen, S. Efrima, J. Phys. Chem., B 103 (1999) 7238.

[34] A. Jellibi, I. Chaabane, K. Guidara, Physica, E. 79 (2016) 167.

[35] P. Harvey, C. Reber Can, J. Chem., 77 (1999) 77.

[36] A. H. Ammar, A. A. M. Farag, M. S. Abo-Ghazala, J. Alloys Compd., 694 (2017) 752.

[37] H. Kchaou, K. Karoui, K. Khirouni, A. Ben Rhaiem, J. Alloys Compd., 728 (2017) 936.

[38] A.S. Hassanien, Alaa A. Akl, J. Alloys Compd., 684 (2015) 280.

[39] A.S. Hassanien, Alaa A. Akl, J. Alloys Compd., 685 (2016) 733.

[40] S. Sen, R.N.P. Choudhary, P. Pramanik, Physica, B. 387 (2007) 56.

[41] H. Khemakhem, T. Mhiri, A. Daoud, Solid State Ionics, 117 (1999) 337.

[42] G. C. Psarras, E. Manolakaki, G. M. Tsangaris, Compos. Part A., 34 (2003) 1187.

[43] R. Murugaraj, G. Govindaraj, D. George, Mater. Lett., 57 (2003) 1656.

[44] ShA. Mansour, I. S. Yahia, F. Yakuphanoglu, Dyes Pigments, 87 (2010) 144.

[45] U. Akgul, Z. Ergin, M. Sekerci, Y. Atici, Vacuum, 82 (2008) 340.

[46] J. T. Gudmundsson, H. G. Svavarsson, S. Gudjonsson, H. P. Gislason, Phys. B., 340 (2003) 324.

[47] T. Winie, A. K. Arof, Ionics, 10 (2004) 193.

[48] S.R. Eliott, J.Adv. Phys. 36 (1987) 135.

[49] Long AR. Adv Phys. 31 (1982)53-673.

\section{Figure captions}

Figure 1: Asymmetric unit of $\left[\mathrm{C}_{7} \mathrm{H}_{16} \mathrm{~N}_{2}\right]\left[\mathrm{ZnCl}_{4}\right]$ showing the atom-numbering scheme involving $\mathrm{N}$ $\mathrm{H} \cdots \mathrm{Cl}$ hydrogen bonding.

Figure 2: View of $\left[\mathrm{C}_{7} \mathrm{H}_{16} \mathrm{~N}_{2}\right]\left[\mathrm{ZnCl}_{4}\right]$ along the $b$-axis. The dotted lines indicate the hydrogen bonds.

Figure 3: $\mathrm{Zn} . . . \mathrm{Zn}$ distances between the anions layers in $\left[\mathrm{C}_{7} \mathrm{H}_{16} \mathrm{~N}_{2}\right]\left[\mathrm{ZnCl}_{4}\right]$.

Figure 4 (a) and (b): Experimental Raman and IR spectra of $\left[\mathrm{C}_{7} \mathrm{H}_{16} \mathrm{~N}_{2}\right]\left[\mathrm{ZnCl}_{4}\right]$.

Figure 5 A, B, C and D: Variation of the absorbance with wavelength (A), $(\alpha h v)^{2}$ vs. hv (B), $(\alpha h v)^{1 / 2}$ vs. hv (C), and determination of Urbach energy (D) for $\left[\mathrm{C}_{7} \mathrm{H}_{16} \mathrm{~N}_{2}\right]\left[\mathrm{ZnCl}_{4}\right]$.

Figure 6: Differential scanning calorimetric of the $\left[\mathrm{C}_{7} \mathrm{H}_{16} \mathrm{~N}_{2}\right]\left[\mathrm{ZnCl}_{4}\right]$. 
Figure 7 (a) and (b) : Temperature dependence of the real and imaginary dielectric constant, (c) Temperature dependence of the dielectric constant 1/e' for $\left[\mathrm{C}_{7} \mathrm{H}_{16} \mathrm{~N}_{2}\right]\left[\mathrm{ZnCl}_{4}\right]$.

Figure 8 A, B, C and D: Nyquist diagram spectra as a function of temperature with electrical equivalent circuit for $\left[\mathrm{C}_{7} \mathrm{H}_{16} \mathrm{~N}_{2}\right]\left[\mathrm{ZnCl}_{4}\right]$.

Figure 9: Variation of the $\mathrm{Ln}\left(\sigma_{\mathrm{g}}\right)$ versus $1000 / \mathrm{T}$ for $\left[\mathrm{C}_{7} \mathrm{H}_{16} \mathrm{~N}_{2}\right]\left[\mathrm{ZnCl}_{4}\right]$.

Figure 10: Frequency dependence of $\mathrm{AC}$ conductivity at various temperatures for $\left[\mathrm{C}_{7} \mathrm{H}_{16} \mathrm{~N}_{2}\right]\left[\mathrm{ZnCl}_{4}\right]$.

Figure 11: Variation of the $\operatorname{Ln}\left(\sigma_{\mathrm{dc}}\right)$ versus $1000 / \mathrm{T}$ for $\left[\mathrm{C}_{7} \mathrm{H}_{16} \mathrm{~N}_{2}\right]\left[\mathrm{ZnCl}_{4}\right]$.

Figure 12: Variation of universal exponent $(\mathrm{S})$ as a function of temperature for $\left[\mathrm{C}_{7} \mathrm{H}_{16} \mathrm{~N}_{2}\right]\left[\mathrm{ZnCl}_{4}\right]$.

Figure 13: Temperature dependence of AC conductivity for $\left[\mathrm{C}_{7} \mathrm{H}_{16} \mathrm{~N}_{2}\right]\left[\mathrm{ZnCl}_{4}\right]$.

\section{Table captions}

Table 1: Crystallographic data and structure refinement parameters for $\left[\mathrm{C}_{7} \mathrm{H}_{16} \mathrm{~N}_{2}\right]\left[\mathrm{ZnCl}_{4}\right]$.

Table 2: Selected bond distances $(\AA)$ and angles $\left({ }^{\circ}\right)$ for $\left[\mathrm{C}_{7} \mathrm{H}_{16} \mathrm{~N}_{2}\right]\left[\mathrm{ZnCl}_{4}\right]$.

Table 3: Hydrogen-bonding geometry $\left(\AA,^{\circ}\right)$ for $\left[\mathrm{C}_{7} \mathrm{H}_{16} \mathrm{~N}_{2}\right]\left[\mathrm{ZnCl}_{4}\right]$.

Table 4: Experimental Raman and IR frequencies $\left(\mathrm{cm}^{-1}\right)$ for $\left[\mathrm{C}_{7} \mathrm{H}_{16} \mathrm{~N}_{2}\right]\left[\mathrm{ZnCl}_{4}\right]$.

Table 5: Parameters for NSPT, OLPT and CBH models fitting in phases I, II, III and IV. 


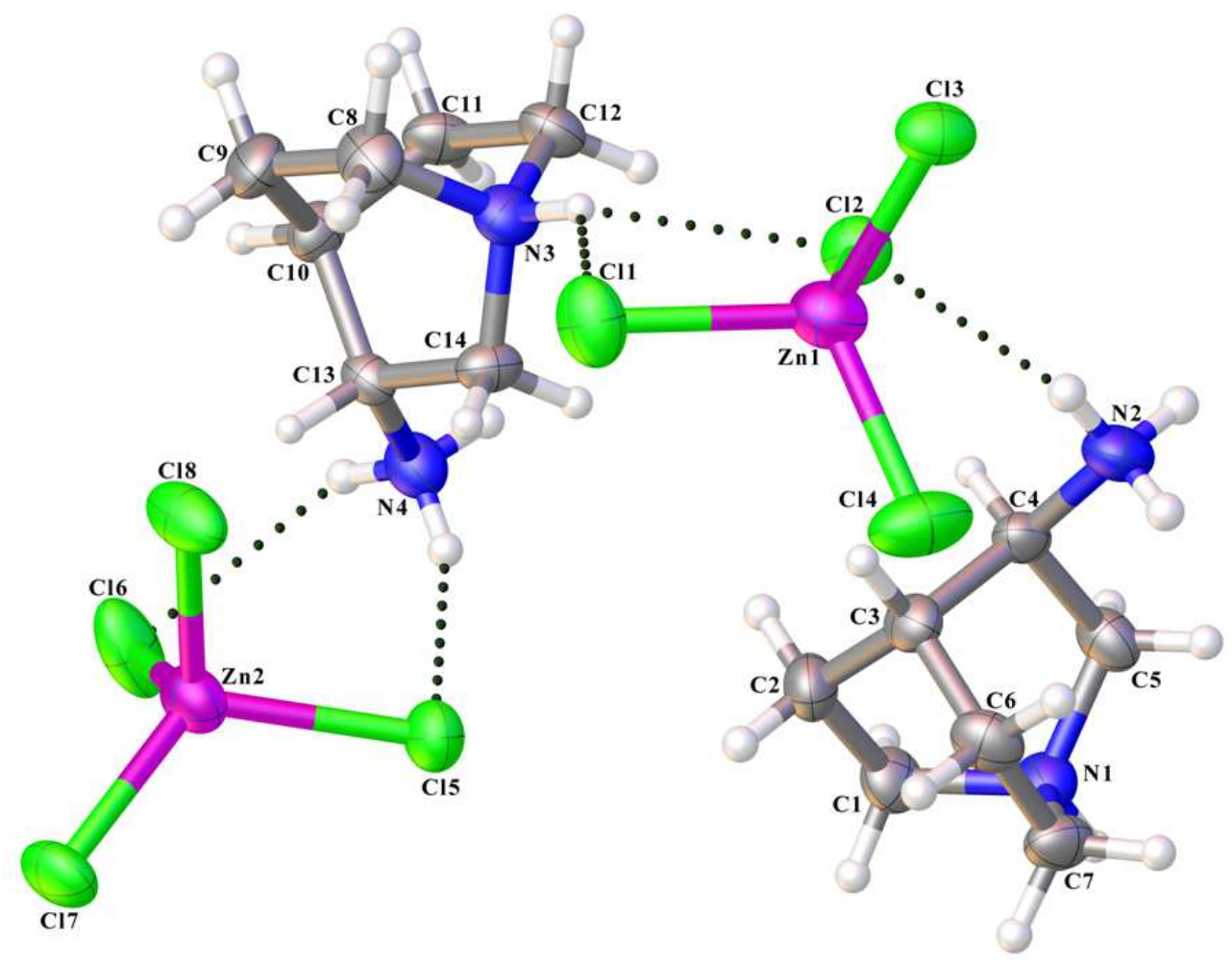

Figure 1: The asymmetric unit of $\left[\mathrm{C}_{7} \mathrm{H}_{16} \mathrm{~N}_{2}\right]\left[\mathrm{ZnCl}_{4}\right]$ showing the atom-numbering scheme involving $\mathrm{N}-\mathrm{H} \cdots \mathrm{Cl}$ hydrogen bonding. 


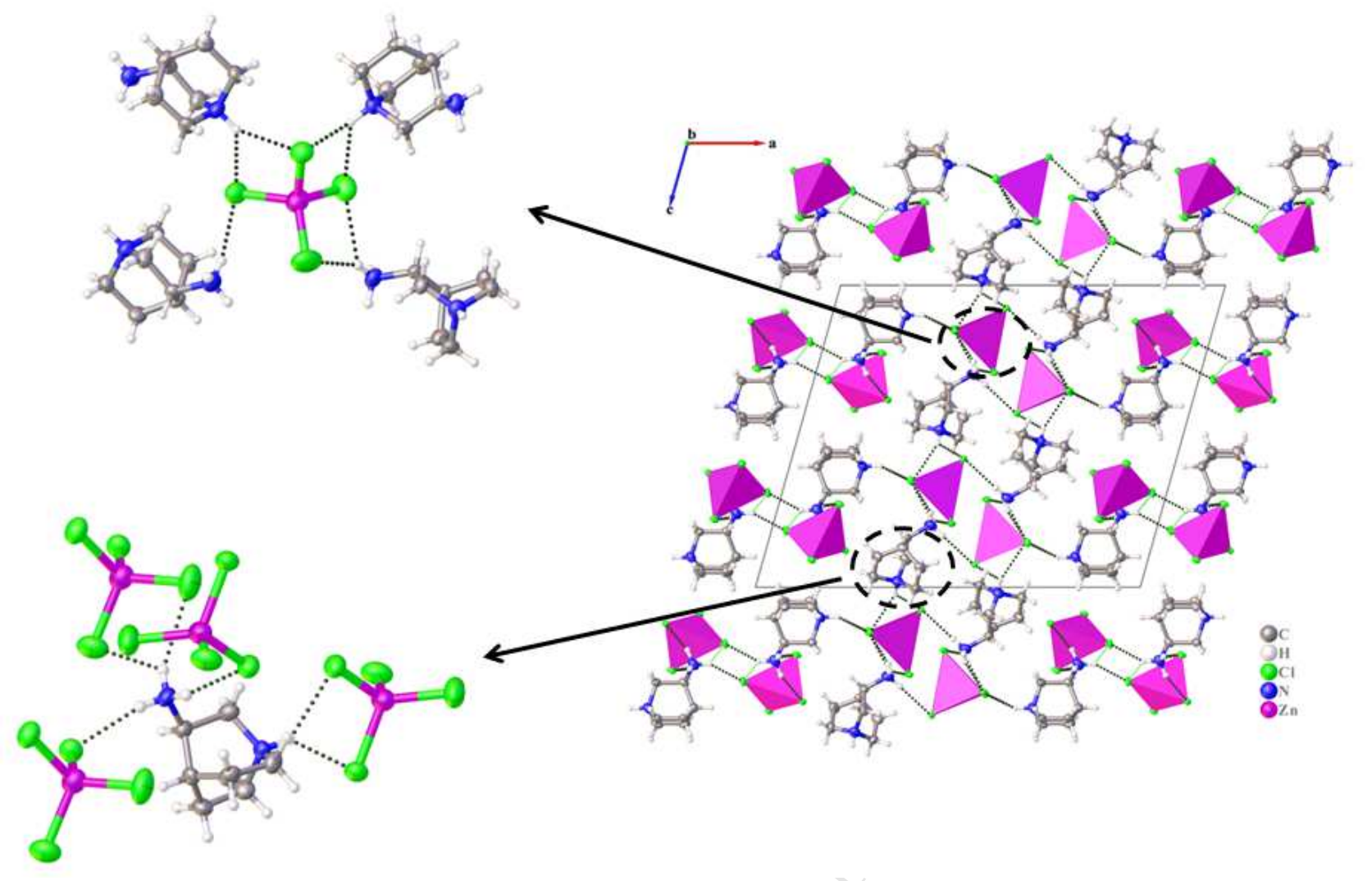

Figure 2: View of $\left[\mathrm{C}_{7} \mathrm{H}_{16} \mathrm{~N}_{2}\right]\left[\mathrm{ZnCl}_{4}\right]$ along the $b$-axis. The dotted lines indicate hydrogen bonds.

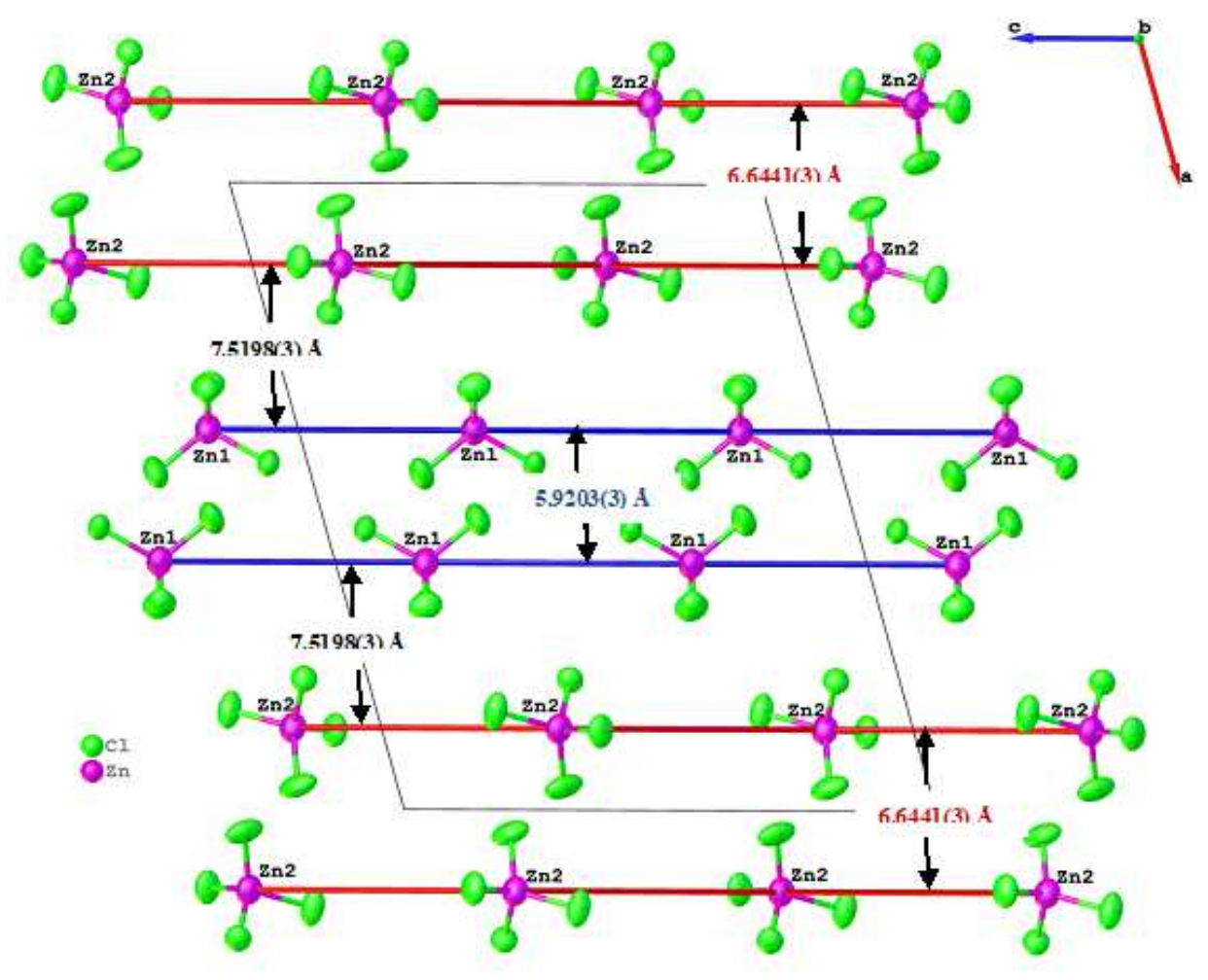

Figure 3: $\mathrm{Zn} . . . \mathrm{Zn}$ distances between the anions layers in $\left[\mathrm{C}_{7} \mathrm{H}_{16} \mathrm{~N}_{2}\right]\left[\mathrm{ZnCl}_{4}\right]$. 


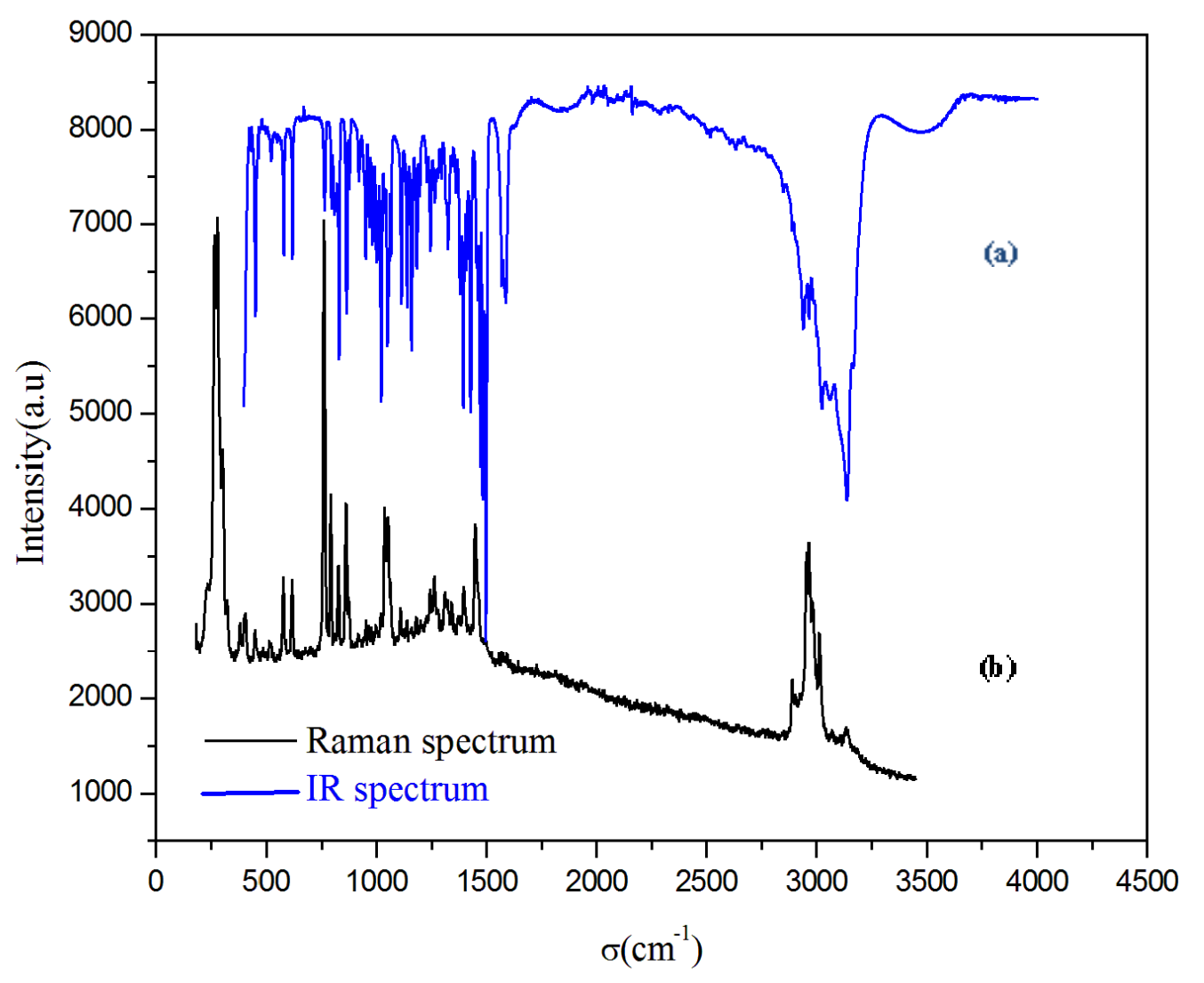

Figure 4 (a) and (b): Experimental Raman and IR spectra of $\left[\mathrm{C}_{7} \mathrm{H}_{16} \mathrm{~N}_{2}\right]\left[\mathrm{ZnCl}_{4}\right]$. 

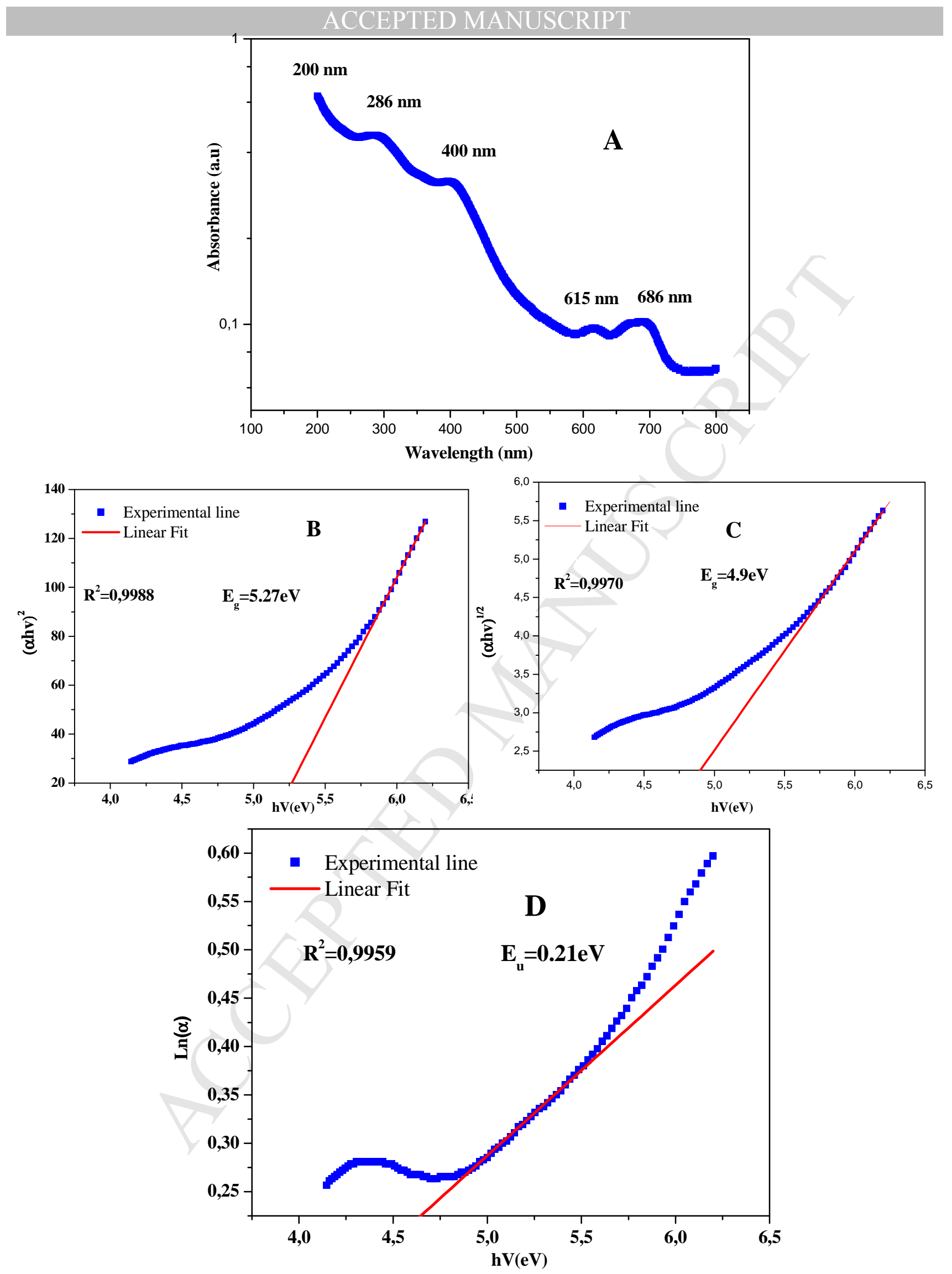

Figure 5 A, B, C and D: Variation of the absorbance with wavelength (A), $(\alpha h v)^{2} v s . h v(B)$, $(\alpha h v)^{1 / 2}$ vs. hv (C), and determination of Urbach energy (D) at room temperature for $\left[\mathrm{C}_{7} \mathrm{H}_{16} \mathrm{~N}_{2}\right]\left[\mathrm{ZnCl}_{4}\right]$. 


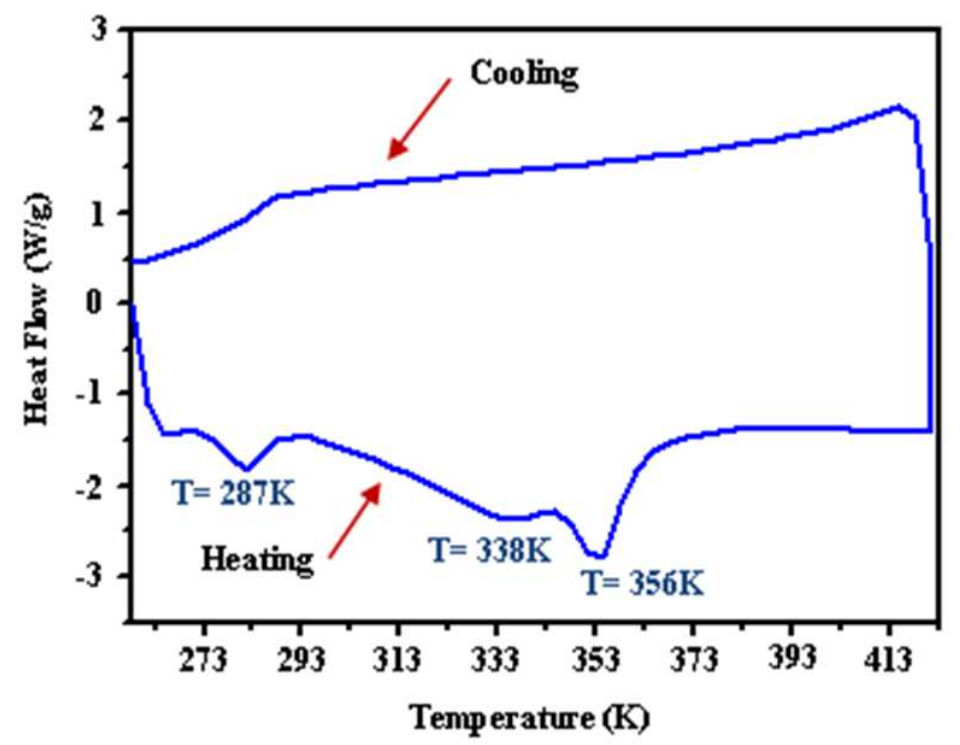

Figure 6: Differential scanning calorimetric of the $\left[\mathrm{C}_{7} \mathrm{H}_{16} \mathrm{~N}_{2}\right]\left[\mathrm{ZnCl}_{4}\right]$.
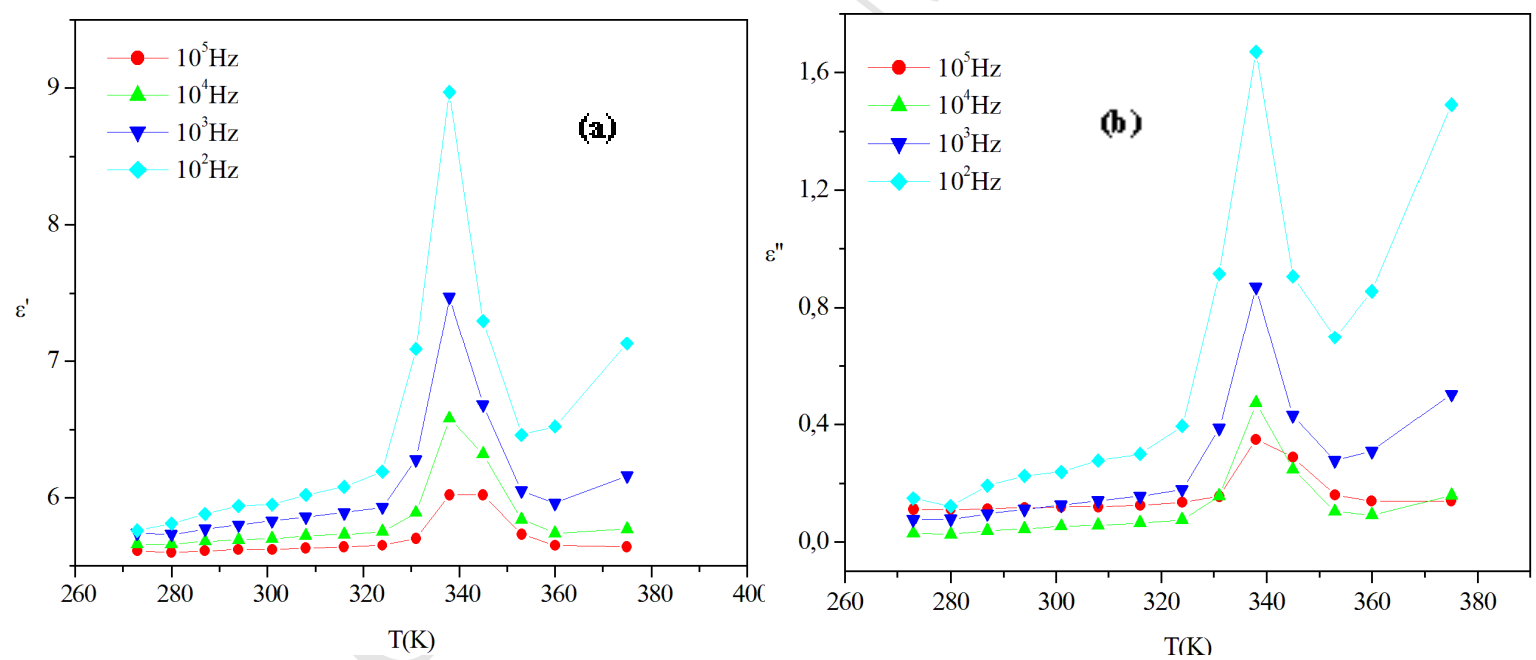


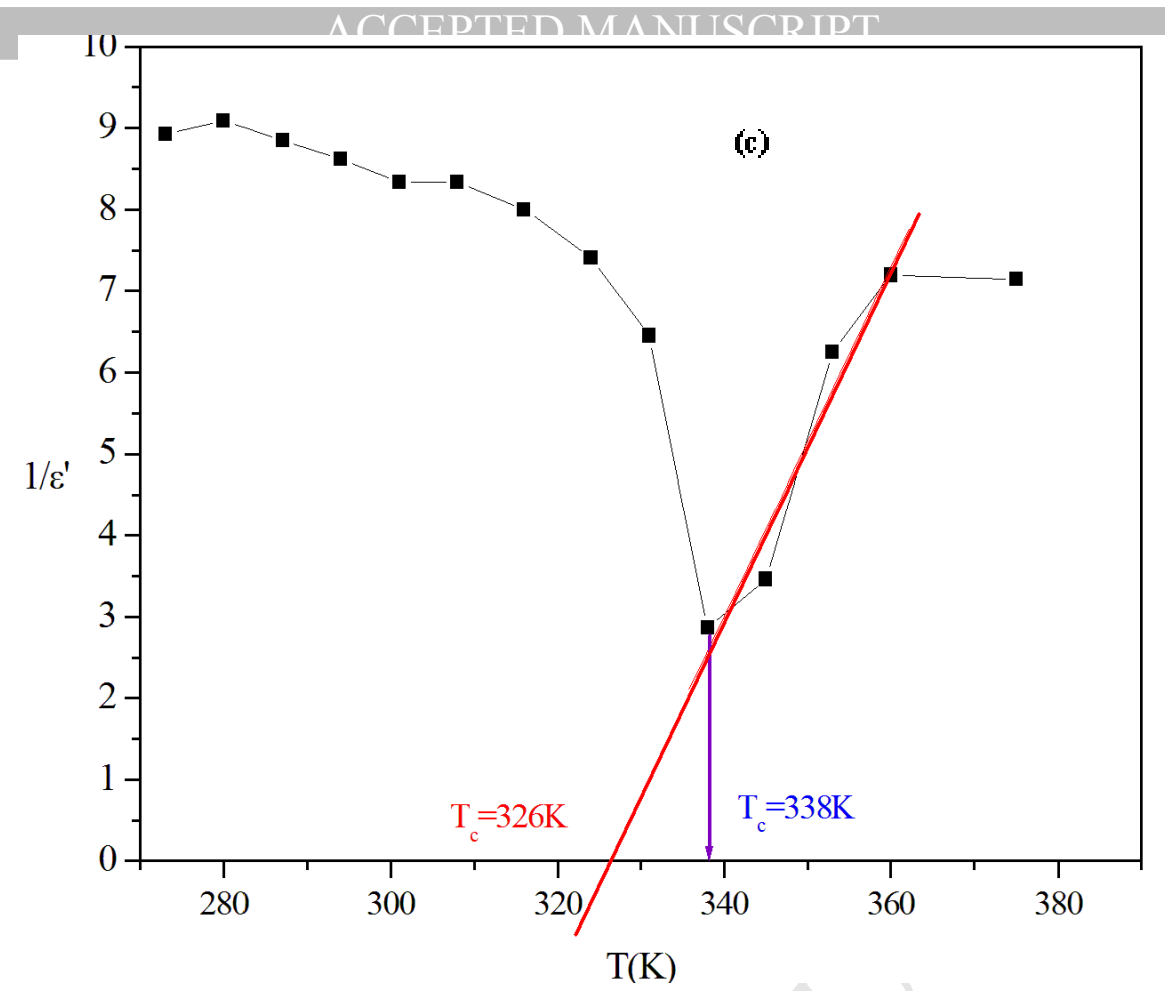

Figure 7 (a) and (b) : Temperature dependence of the real and imaginary dielectric constant, (c) Temperature dependence of the dielectric constant $1 / \varepsilon^{\prime}$ for $\left[\mathrm{C}_{7} \mathrm{H}_{16} \mathrm{~N}_{2}\right]\left[\mathrm{ZnCl}_{4}\right]$. 

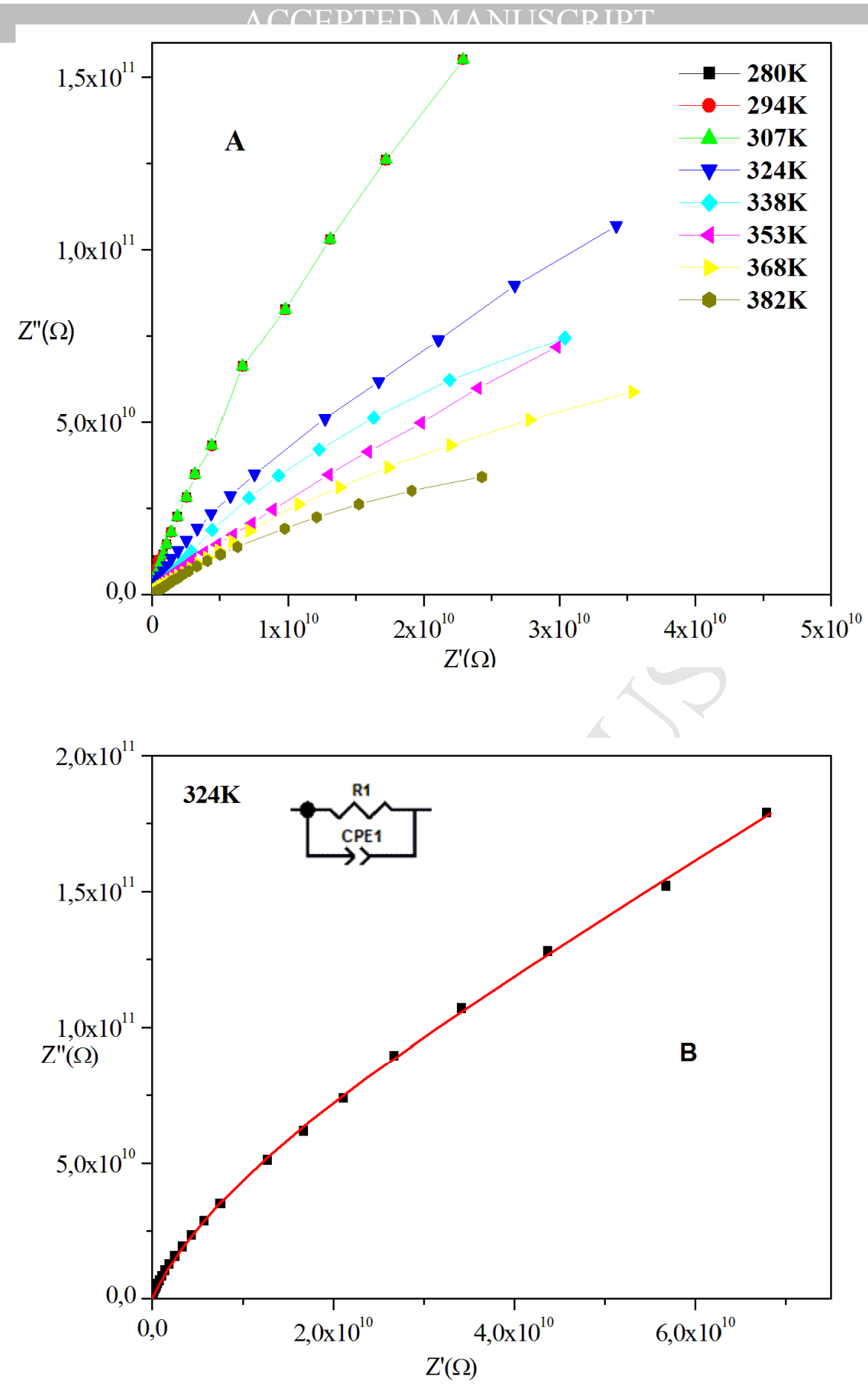

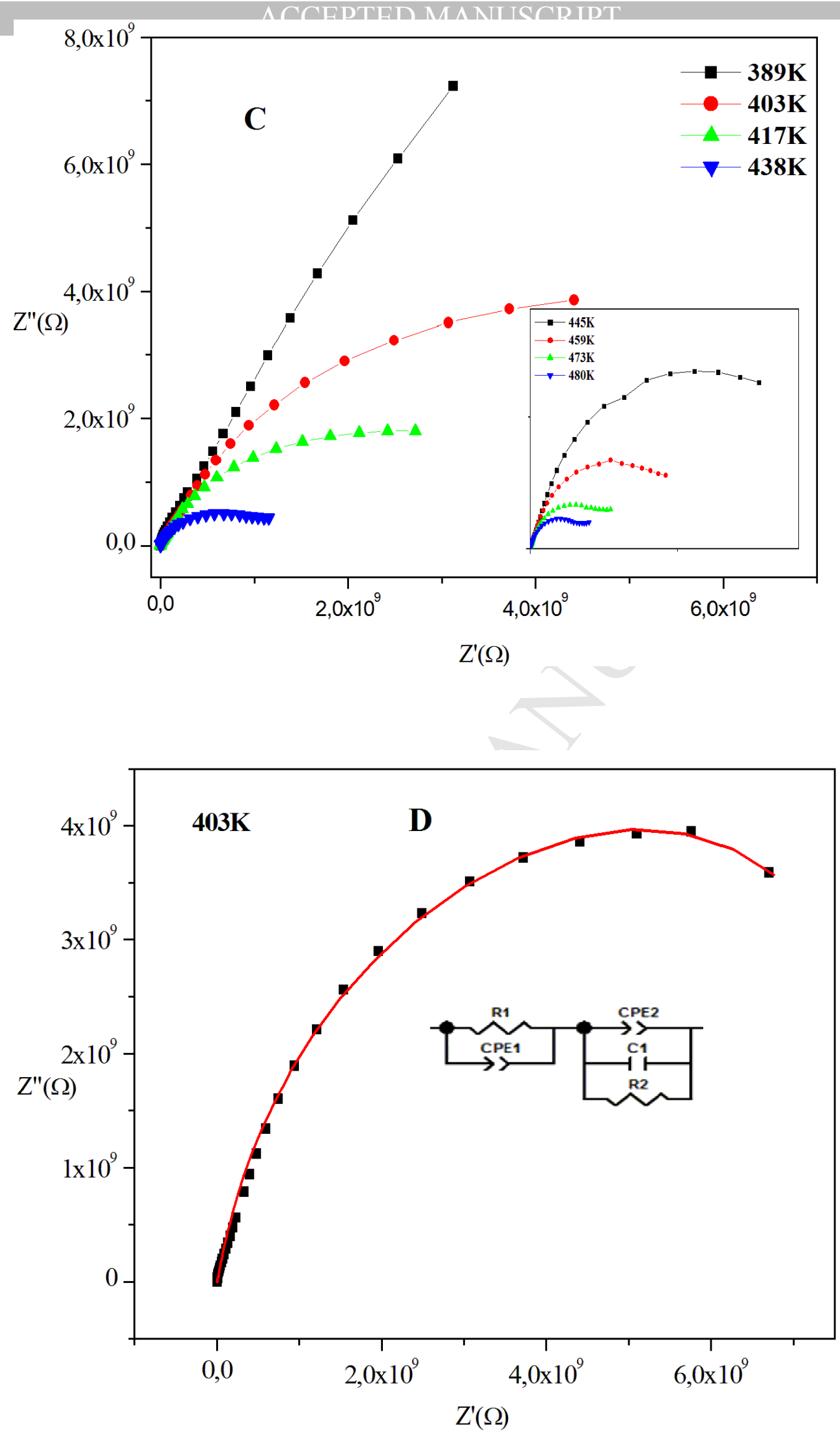

Figure 8 A, B, C and D: Nyquist diagram spectra as a function of temperature with electrical equivalent circuit for $\left[\mathrm{C}_{7} \mathrm{H}_{16} \mathrm{~N}_{2}\right]\left[\mathrm{ZnCl}_{4}\right]$. 


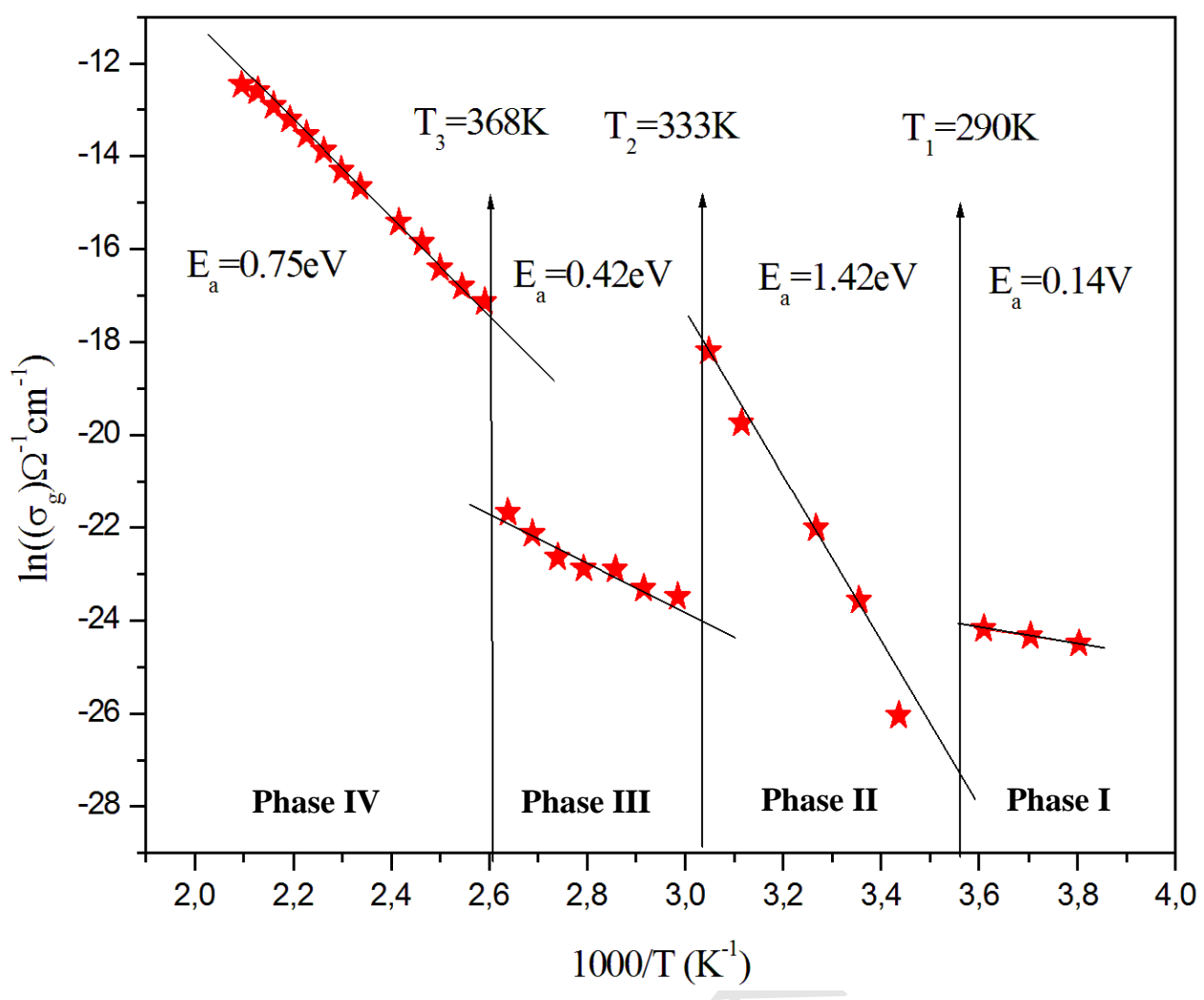

Figure 9: Variation of $\operatorname{Ln}\left(\sigma_{\mathrm{g}}\right)$ versus $1000 / \mathrm{T}$ for $\left[\mathrm{C}_{7} \mathrm{H}_{16} \mathrm{~N}_{2}\right]\left[\mathrm{ZnCl}_{4}\right]$.

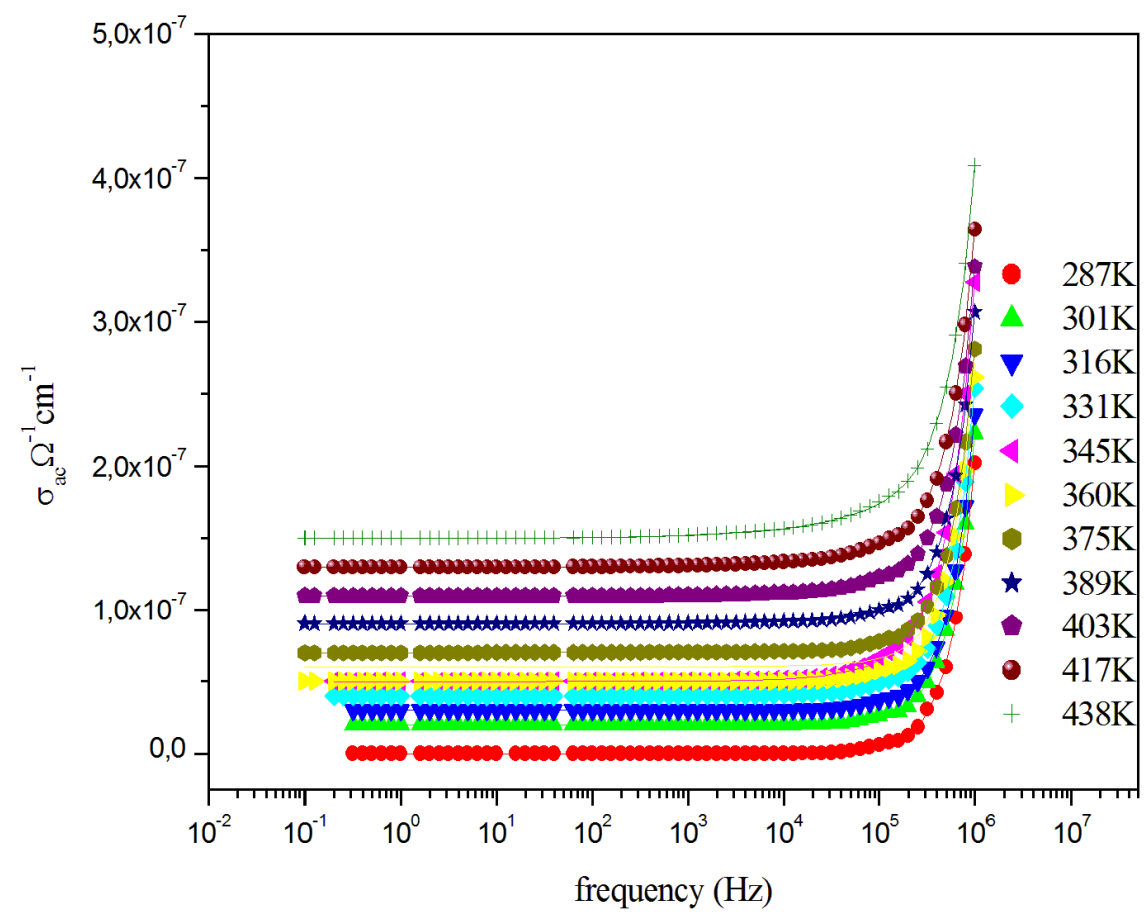

Figure 10: Frequency dependence of $\mathrm{AC}$ conductivity at various temperatures for $\left[\mathrm{C}_{7} \mathrm{H}_{16} \mathrm{~N}_{2}\right]\left[\mathrm{ZnCl}_{4}\right]$. 


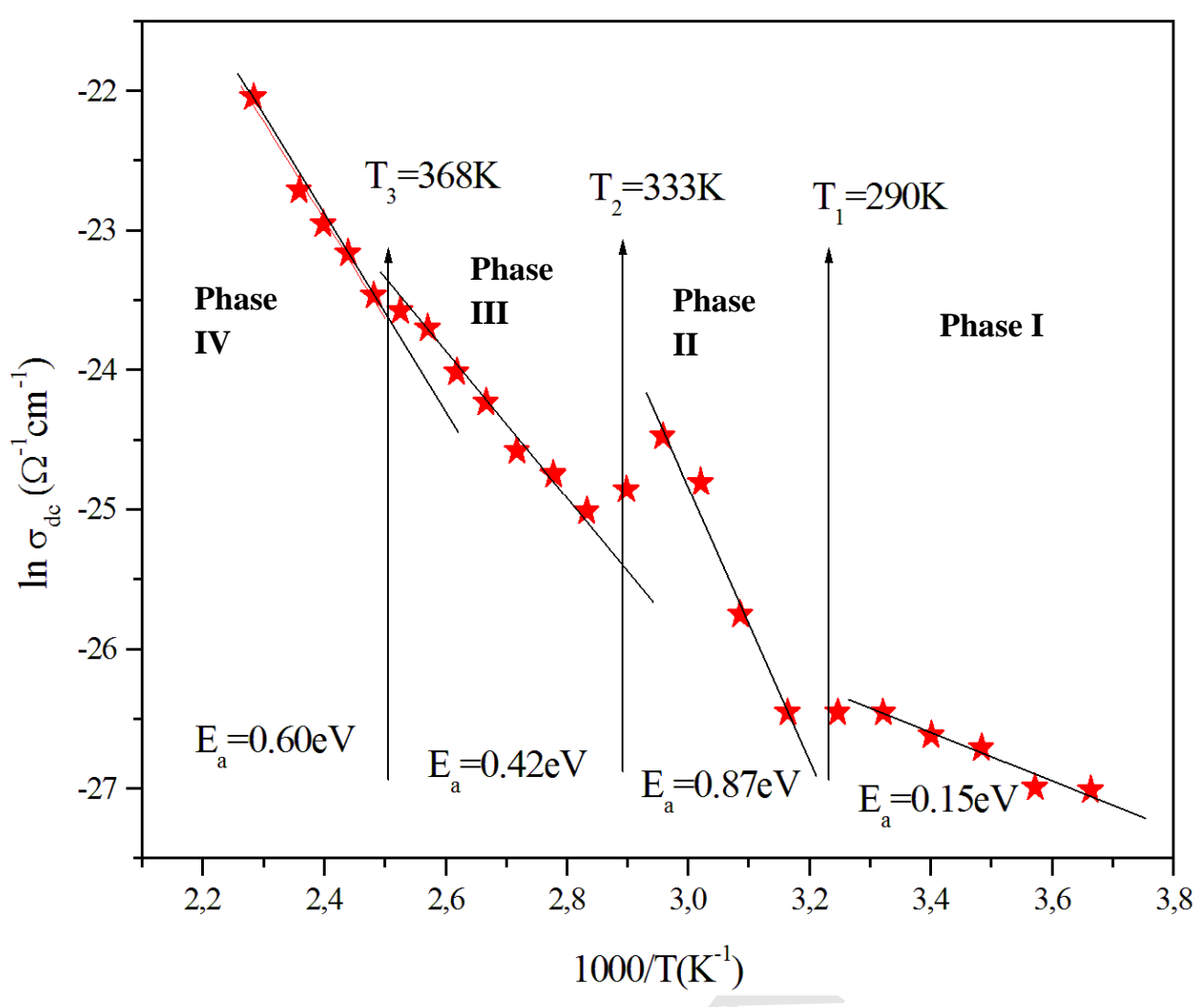

Figure 11: Variation of $\operatorname{Ln}\left(\sigma_{\mathrm{dc}}\right)$ versus $1000 / \mathrm{T}$ for $\left[\mathrm{C}_{7} \mathrm{H}_{16} \mathrm{~N}_{2}\right]\left[\mathrm{ZnCl}_{4}\right]$.

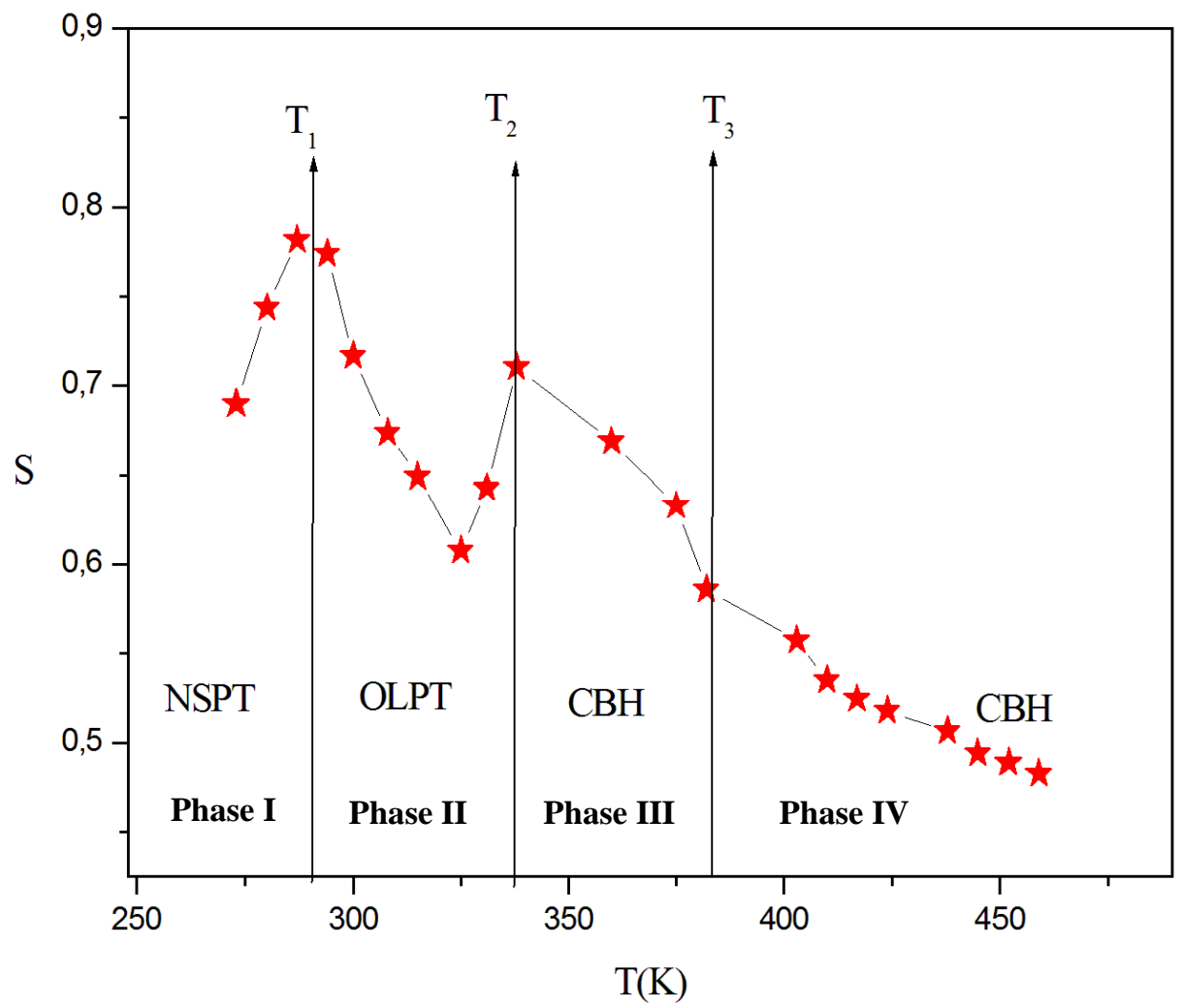

Figure 12: Variation of universal exponent (S) as a function of temperature for $\left[\mathrm{C}_{7} \mathrm{H}_{16} \mathrm{~N}_{2}\right]\left[\mathrm{ZnCl}_{4}\right]$. 


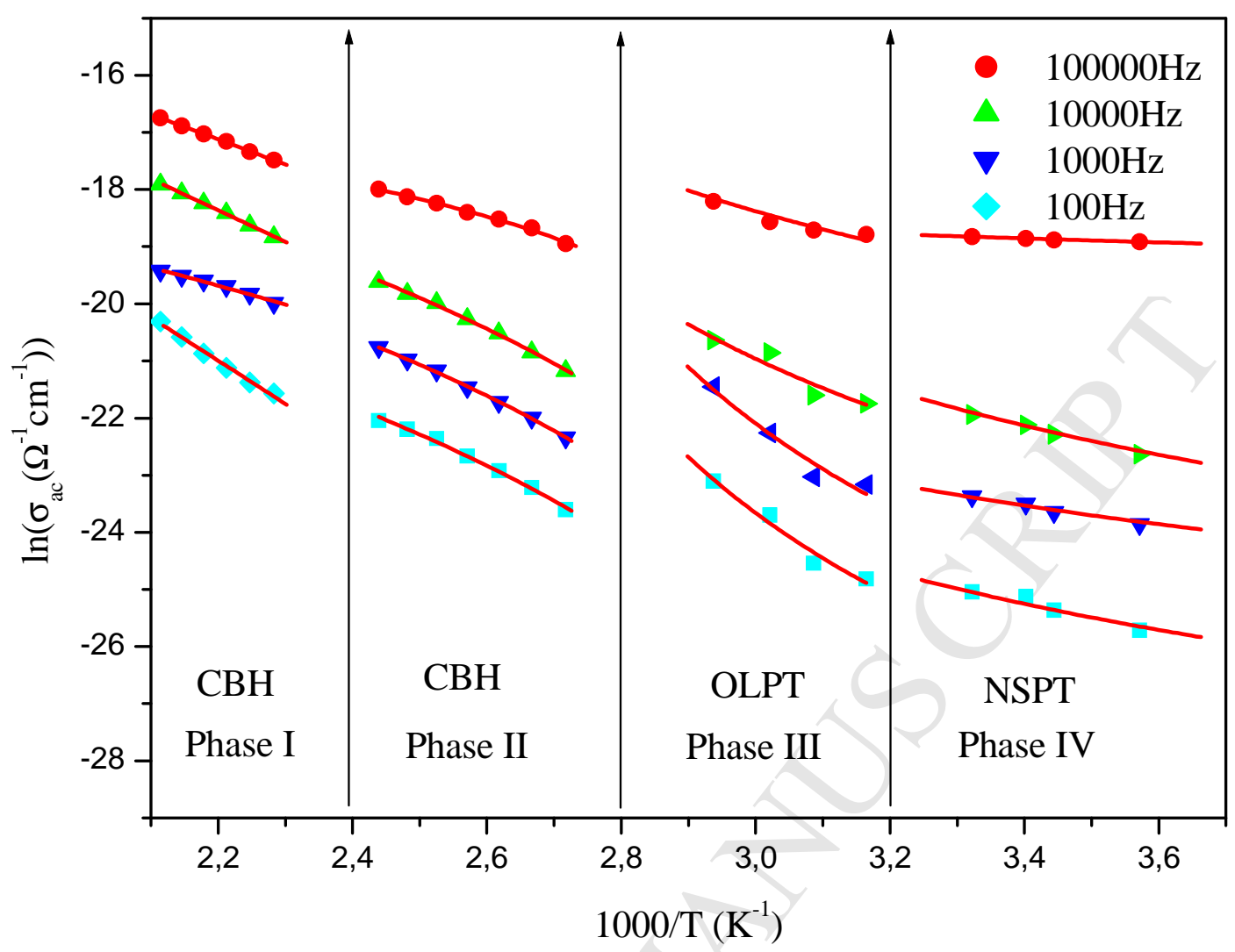

Figure 13: Temperature dependence of $\mathrm{AC}$ conductivity for $\left[\mathrm{C}_{7} \mathrm{H}_{16} \mathrm{~N}_{2}\right]\left[\mathrm{ZnCl}_{4}\right]$. 
Table 1: Crystallographic data and structure refinement parameters for $\left[\mathrm{C}_{7} \mathrm{H}_{16} \mathrm{~N}_{2}\right]\left[\mathrm{ZnCl}_{4}\right]$.

\begin{tabular}{|c|c|}
\hline Empirical formula & $\mathrm{C}_{7} \mathrm{H}_{16} \mathrm{~N}_{2} \mathrm{Cl}_{4} \mathrm{Zn}$ \\
\hline Formula weight $\left(\mathrm{g} \cdot \mathrm{mol}^{-1}\right)$ & 335.41 \\
\hline Temperature $(\mathrm{K})$ & 296 \\
\hline Crystal system & Monoclinic \\
\hline Space group & $P 2_{1} / c$ \\
\hline$a(\AA)$ & $21.3562(13)$ \\
\hline$b(\AA)$ & $7.4060(4)$ \\
\hline$c(\AA)$ & $17.3938(12)$ \\
\hline$\alpha\left({ }^{\circ}\right)$ & 90 \\
\hline$\beta\left(^{\circ}\right)$ & $105.777(3)$ \\
\hline$\gamma\left({ }^{\circ}\right)$ & 90 \\
\hline$V\left(\AA^{3}\right)$ & $2647.4(3)$ \\
\hline $\mathrm{Z}$ & 4 \\
\hline$\lambda(\operatorname{MoK} \alpha)(\AA)$ & 0.71073 \\
\hline$\rho \operatorname{cal}\left(\mathrm{g} \cdot \mathrm{cm}^{-1}\right)$ & 1.683 \\
\hline Absorption correction & Multi-scan \\
\hline$\mu\left(\mathrm{mm}^{-1}\right)$ & 2.630 \\
\hline Crystal size $\left(\mathrm{mm}^{3}\right)$ & $1 \times 0.18 \times 0.11$ \\
\hline Crystal color/shape & Stick colourless \\
\hline$h k l$ range & $-27 \leq \mathrm{h} \leq 27 ;-9 \leq \mathrm{k} \leq 9 ;-22 \leq 1 \leq 20$ \\
\hline$\theta$ range for data collection (deg) & $0.991-27.594$ \\
\hline Refinement method & Full-matrix least-squares on $\mathrm{F}^{2}$ \\
\hline No. of collected reflections & 24699 \\
\hline No. of independent reflections & 6128 \\
\hline $\begin{array}{l}\text { Observed reflections / restrains / parameters / } \\
\text { refined parameters }\end{array}$ & $4455 / 0 / 253$ \\
\hline$R_{\text {int }}$ & 0.053 \\
\hline $\mathrm{F}(000)$ & 1360.0 \\
\hline Goodness of fit & 1.018 \\
\hline Transmission factors & $\mathrm{T}_{\min }=0.4569, \mathrm{~T}_{\max }=0.7456$ \\
\hline $\mathrm{R}$ indices & $\mathrm{R}_{1}=0.039, \mathrm{wR}_{2}=0.095$ \\
\hline Largest difference map hole $\left(\mathrm{e} \AA^{-3}\right)$ & $\Delta \rho_{\max }=0.97, \Delta \rho_{\min }=-0.85$ \\
\hline
\end{tabular}


Table 2: Selected bond distances $(\AA)$ and angles $\left(^{\circ}\right)$ for $\left[\mathrm{C}_{7} \mathrm{H}_{16} \mathrm{~N}_{2}\right]\left[\mathrm{ZnCl}_{4}\right]$.

\begin{tabular}{|c|c|c|c|}
\hline $\mathrm{Zn} 1-\mathrm{Cl} 4$ & $2.2323(11)$ & $\mathrm{N} 3-\mathrm{C} 14$ & $1.490(4)$ \\
\hline $\mathrm{Zn} 1-\mathrm{Cl1}$ & $2.2581(10)$ & $\mathrm{N} 3-\mathrm{C} 12$ & $1.501(4)$ \\
\hline $\mathrm{Zn} 1-\mathrm{Cl} 3$ & $2.2788(10)$ & N3-C8 & $1.497(4)$ \\
\hline $\mathrm{Zn} 1-\mathrm{Cl} 2$ & $2.2848(9)$ & $\mathrm{N} 1-\mathrm{C} 7$ & $1.494(4)$ \\
\hline $\mathrm{Zn} 2-\mathrm{Cl} 7$ & $2.2317(9)$ & $\mathrm{N} 1-\mathrm{C} 5$ & $1.492(4)$ \\
\hline $\mathrm{Zn} 2-\mathrm{Cl} 6$ & $2.2664(10)$ & $\mathrm{N} 1-\mathrm{C} 1$ & $1.493(4)$ \\
\hline $\mathrm{Zn} 2-\mathrm{Cl} 18$ & $2.2927(10)$ & N4_-C13 & $1.493(4)$ \\
\hline $\mathrm{Zn} 2-\mathrm{Cl} 5$ & $2.3056(9)$ & N2-C4 & $1.497(4)$ \\
\hline $\mathrm{Cl} 4-\mathrm{Zn} 1-\mathrm{Cl} 1$ & $108.78(5)$ & C14_C13 & $1.527(4)$ \\
\hline $\mathrm{Cl} 4-\mathrm{Zn} 1-\mathrm{Cl} 3$ & $111.23(4)$ & C3-C6 & $1.520(5)$ \\
\hline $\mathrm{Cl} 1-\mathrm{Zn} 1-\mathrm{Cl} 3$ & $112.84(4)$ & $\mathrm{C} 3-\mathrm{C} 2$ & $1.523(5)$ \\
\hline $\mathrm{Cl} 4-\mathrm{Zn} 1-\mathrm{Cl} 2$ & $115.84(4)$ & $\mathrm{C} 3-\mathrm{C} 4$ & $1.528(5)$ \\
\hline $\mathrm{Cl} 1-\mathrm{Zn} 1-\mathrm{Cl} 2$ & $105.57(4)$ & $\mathrm{C} 13-\mathrm{C} 10$ & $1.522(5)$ \\
\hline $\mathrm{Cl} 3-\mathrm{Zn} 1-\mathrm{Cl} 2$ & $102.46(4)$ & $\mathrm{C} 4-\mathrm{C} 5$ & $1.529(5)$ \\
\hline $\mathrm{Cl} 7-\mathrm{Zn} 2-\mathrm{Cl} 6$ & $110.42(4)$ & $\mathrm{C} 10-\mathrm{C} 11$ & $1.528(5)$ \\
\hline $\mathrm{Cl} 7-\mathrm{Zn} 2-\mathrm{Cl} 8$ & $107.00(4)$ & C10-C9 & $1.535(5)$ \\
\hline $\mathrm{Cl} 6-\mathrm{Zn} 2-\mathrm{Cl} 8$ & $117.33(5)$ & $\mathrm{C} 11-\mathrm{C} 12$ & $1.522(5)$ \\
\hline $\mathrm{Cl} 7-\mathrm{Zn} 2-\mathrm{Cl} 5$ & $119.00(4)$ & $\mathrm{C} 8-\mathrm{C} 9$ & $1.517(5)$ \\
\hline $\mathrm{Cl} 6-\mathrm{Zn} 2-\mathrm{Cl} 5$ & $101.29(4)$ & $\mathrm{C} 1-\mathrm{C} 2$ & $1.523(5)$ \\
\hline $\mathrm{Cl} 18-\mathrm{Zn} 2-\mathrm{Cl} 5$ & $102.07(4)$ & C7-C6 & $1.521(5)$ \\
\hline N1-C7-C6 & $108.4(3)$ & $\mathrm{C} 14-\mathrm{N} 3-\mathrm{C} 12$ & $109.9(3)$ \\
\hline $\mathrm{C} 8-\mathrm{C} 9-\mathrm{C} 10$ & $109.6(3)$ & C14-N3-C8 & $110.2(3)$ \\
\hline C3-C6-C7 & $110.1(3)$ & $\mathrm{C} 12-\mathrm{N} 3-\mathrm{C} 8$ & $110.9(3)$ \\
\hline $\mathrm{N} 1-\mathrm{C} 5-\mathrm{C} 4$ & $108.9(3)$ & C7-N1-C5 & $110.5(3)$ \\
\hline $\mathrm{N} 3-\mathrm{C} 12-\mathrm{C} 11$ & $109.3(3)$ & $\mathrm{C} 7-\mathrm{N} 1-\mathrm{C} 1$ & $110.4(3)$ \\
\hline $\mathrm{N} 1-\mathrm{C} 1-\mathrm{C} 2$ & $108.8(3)$ & $\mathrm{C} 5-\mathrm{N} 1-\mathrm{C} 1$ & $110.8(3)$ \\
\hline $\mathrm{C} 3-\mathrm{C} 2-\mathrm{C} 1$ & $109.7(3)$ & N3_C14-C13 & $108.7(3)$ \\
\hline $\mathrm{C} 11-\mathrm{C} 10-\mathrm{C} 13$ & $111.0(3)$ & $\mathrm{C} 6-\mathrm{C} 3-\mathrm{C} 2$ & $109.4(3)$ \\
\hline $\mathrm{C} 11-\mathrm{C} 10-\mathrm{C} 9$ & $108.5(3)$ & $\mathrm{C} 6-\mathrm{C} 3-\mathrm{C} 4$ & $110.0(3)$ \\
\hline C13-C10-C9 & $106.2(3)$ & $\mathrm{C} 2-\mathrm{C} 3-\mathrm{C} 4$ & $106.8(3)$ \\
\hline $\mathrm{C} 12-\mathrm{C} 11-\mathrm{C} 10$ & $109.6(3)$ & N4-C13-C10 & $113.3(3)$ \\
\hline N3-C8-C9 & $109.4(3)$ & N4-C13_C14 & $109.8(3)$ \\
\hline $\mathrm{N} 2-\mathrm{C} 4-\mathrm{C} 5$ & $110.1(3)$ & C10-C13-C14 & $110.0(3)$ \\
\hline $\mathrm{C} 3-\mathrm{C} 4-\mathrm{C} 5$ & $109.0(3)$ & $\mathrm{N} 2-\mathrm{C} 4-\mathrm{C} 3$ & $112.1(3)$ \\
\hline
\end{tabular}


Table 3: Hydrogen-bonding geometry $\left(\AA{ }^{\circ}{ }^{\circ}\right)$ for $\left[\mathrm{C}_{7} \mathrm{H}_{16} \mathrm{~N}_{2}\right]\left[\mathrm{ZnCl}_{4}\right]$.

\begin{tabular}{|c|c|c|c|c|}
\hline D-H・AA & D-H & $\mathbf{H} \cdots A$ & $D \cdots A$ & D-H $\cdots A$ \\
\hline $\mathrm{N} 3-\mathrm{H} 3 \cdots \mathrm{Cl} 2$ & 0.98 & 2.65 & $3.372(3)$ & 131 \\
\hline $\mathrm{N} 3-\mathrm{H} 3 \cdots \mathrm{Cl} 1$ & 0.98 & 2.62 & $3.338(3)$ & 130 \\
\hline $\mathrm{N} 1-\mathrm{H} 1 \cdots \mathrm{Cl} 2^{(\mathrm{i})}$ & 0.98 & 2.58 & $3.388(3)$ & 140 \\
\hline $\mathrm{N} 1-\mathrm{H} 1 \cdots \mathrm{Cl} 3^{(\mathrm{i})}$ & 0.98 & 2.58 & $3.316(3)$ & 132 \\
\hline N4-H4A $\cdots \mathrm{Cl} 5$ & 0.89 & 2.68 & $3.445(3)$ & 144 \\
\hline N4_-H4B $\cdots \mathrm{Cl} 6$ & 0.89 & 2.77 & $3.229(3)$ & 114 \\
\hline $\mathrm{N} 4-\mathrm{H} 4 \mathrm{~B} \cdots \mathrm{Cl6}{ }^{\text {(ii) }}$ & 0.89 & 2.48 & $3.157(3)$ & 133 \\
\hline $\mathrm{N} 4-\mathrm{H} 4 \mathrm{C} \cdots \mathrm{Cl} 8^{\text {(iii) }}$ & 0.89 & 2.36 & $3.217(3)$ & 163 \\
\hline $\mathrm{N} 2-\mathrm{H} 2 \mathrm{~A} \cdots \mathrm{Cl1}{ }^{\text {(iii) }}$ & 0.89 & 2.71 & $3.294(3)$ & 125 \\
\hline $\mathrm{N} 2-\mathrm{H} 2 \mathrm{~A} \cdots \mathrm{Cl} 4^{(\mathrm{iii})}$ & 0.89 & 2.77 & $3.583(3)$ & 152 \\
\hline $\mathrm{N} 2-\mathrm{H} 2 \mathrm{~B} \cdots \mathrm{Cl} 2$ & 0.89 & 2.44 & $3.255(3)$ & 153 \\
\hline $\mathrm{N} 2-\mathrm{H} 2 \mathrm{C} \cdots \mathrm{Cl} 3^{\text {(iv) }}$ & 0.89 & 2.42 & $3.268(3)$ & 159 \\
\hline
\end{tabular}

Symmetry codes : ${ }^{(i)} \mathrm{x},-\mathrm{y}-3 / 2, \mathrm{z}-1 / 2 ;{ }^{(i i)}-\mathrm{x}+2, \mathrm{y}-1 / 2,-\mathrm{z}+3 / 2 ;{ }^{\text {(iii) }} \mathrm{x}, \mathrm{y}-1, \mathrm{z} ;{ }^{(\mathrm{iv})}-\mathrm{x}+1, \mathrm{y}-1 / 2,-\mathrm{z}+3 / 2$.

Table 4 : Experimental Raman and IR frequencies $\left(\mathrm{cm}^{-1}\right)$ for $\left[\mathrm{C}_{7} \mathrm{H}_{16} \mathrm{~N}_{2}\right]\left[\mathrm{ZnCl}_{4}\right]$.

\begin{tabular}{|c|c|c|}
\hline $\begin{array}{c}\text { Experimental } \\
\text { Infrared frequencies } \\
\left(\mathbf{c m}^{-\mathbf{1}}\right)\end{array}$ & $\begin{array}{c}\text { Experimental Raman } \\
\text { frequencies }\left(\mathbf{c m}^{-\mathbf{1}}\right)\end{array}$ & Attribution \\
\hline \multirow{2}{*}{ inactive } & 230 & $v_{4}\left(\mathrm{ZnCl}_{4}\right)$ \\
\cline { 2 - 3 } & $278 / 306$ & $v_{1}\left(\mathrm{ZnCl}_{4}\right)$ \\
\hline 452 & 379 & $v_{3}\left(\mathrm{ZnCl}_{4}\right)$ \\
\hline 573 & 402 & $\rho\left(\mathrm{CH}_{2}\right)$ \\
\hline 617 & 450 & $\left.\delta(\mathrm{NH})_{2}\right)$ \\
\hline 760 & 612 & $\delta(\mathrm{NH}-\mathrm{H})$ \\
\hline 805 & 760 & $v(\mathrm{~N}-\mathrm{C})$ \\
\hline 827 & 792 & $v(\mathrm{~N}-\mathrm{C})$ \\
\hline & 830 & $\delta(\mathrm{C}-\mathrm{N}-\mathrm{C})$ \\
\hline & & \\
\hline
\end{tabular}




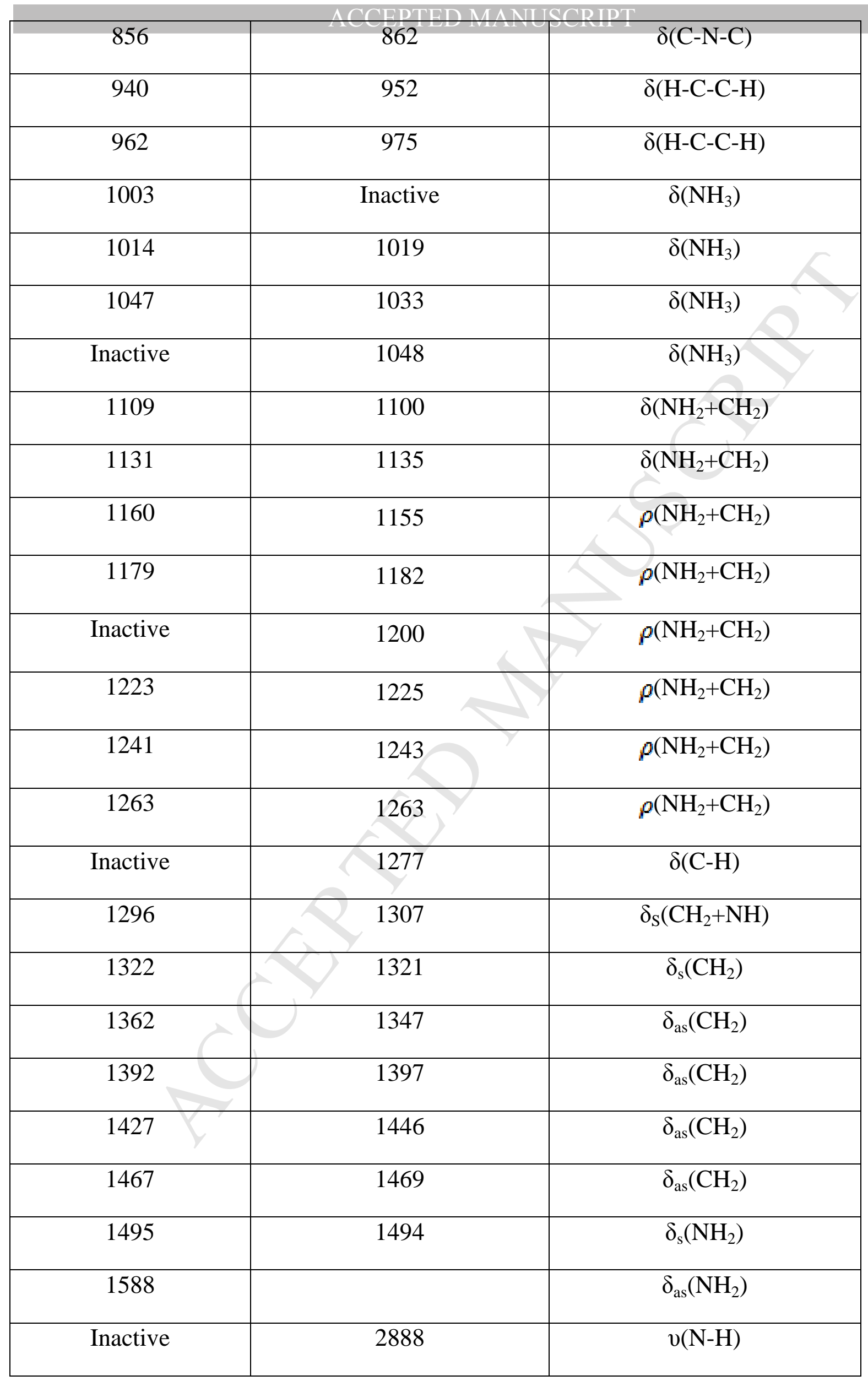




\begin{tabular}{|c|c|c|}
\hline Inactive & 2907 & $\mathrm{v}_{\mathrm{s}}\left(\mathrm{CH}_{2}\right)$ \\
\hline 2932 & 2949 & $\mathrm{v}_{\mathrm{s}}\left(\mathrm{CH}_{2}\right)$ \\
\hline Inactive & 2963 & $\mathrm{v}_{\mathrm{s}}\left(\mathrm{CH}_{2}\right)$ \\
\hline Inactive & 2977 & $\mathrm{v}_{\mathrm{s}}\left(\mathrm{CH}_{2}\right)$ \\
\hline 3019 & 3015 & $\mathrm{v}_{\mathrm{as}}\left(\mathrm{CH}_{2}\right)$ \\
\hline 3065 & 3070 & $\mathrm{v}_{\mathrm{as}}\left(\mathrm{CH}_{2}\right)$ \\
\hline 3139 & 3131 & $\mathrm{v}(\mathrm{N}-\mathrm{H})$ \\
\hline
\end{tabular}

Table 5 : Parameters for NSPT, OLPT and CBH models fitting in phases I, II, III and IV.

\begin{tabular}{|c|c|c|c|c|c|c|c|c|c|}
\hline & \multicolumn{2}{|c|}{$\begin{array}{c}\text { Phase I : } \\
\text { NSPT }\end{array}$} & \multicolumn{2}{c|}{ PhaseI I : OLPT } & \multicolumn{2}{l|}{$\begin{array}{l}\text { Phase III: } \\
\text { CBH }\end{array}$} & \multicolumn{2}{l|}{ Phase IV: CBH } \\
\hline $\begin{array}{c}\text { Frequence } \\
(\mathrm{Hz})\end{array}$ & $\mathrm{N}(\mathrm{E} 18)$ & $\mathrm{W}_{\mathrm{H}}$ & $\mathrm{N}(\mathrm{E} 18)$ & $\mathrm{W}_{\mathrm{H}}$ & $\mathrm{r}_{\mathrm{p}}(\mathrm{E}-$ \\
$10)$ & $\mathrm{N}(\mathrm{E} 18)$ & $\mathrm{W}_{\mathrm{H}}$ & $\mathrm{N}(\mathrm{E} 18)$ & $\mathrm{W}_{\mathrm{H}}$ \\
\hline 100000 & 33.5 & 1.438 & 5.78 & 0.305 & 0.021 & 23.78 & 0.716 & 7.59 & 1.045 \\
\hline 10000 & 11 & 1.277 & 1.68 & 0.411 & 0.014 & 8.71 & 0.737 & 5.59 & 1.061 \\
\hline 1000 & 1.56 & 1.067 & 1.22 & 0.463 & 0.443 & 2.74 & 0.746 & 5.33 & 1.019 \\
\hline 100 & 0.91 & 1.012 & 0.9 & 0.522 & 0.614 & 0.47 & 0.828 & 4.01 & 1.09 \\
\hline
\end{tabular}




\section{Highlights}

- A new compound " $\left[\mathrm{C}_{7} \mathrm{H}_{16} \mathrm{~N}_{2}\right]\left[\mathrm{ZnCl}_{4}\right]$ " was synthesized at room temperature and crystallizes in the monoclinic system with $\mathrm{P} 21 / \mathrm{c}$ space group.

- The DSC shows three sequential phase transitions at 287, 338 and $356 \mathrm{~K}$.

- The dielectric study proved the ferroelectric properties at $338 \mathrm{~K}$.

- The optical absorption reveals four bands at 200, 286, 400 and $680 \mathrm{~nm}$.

- Equivalent circuit was discussed and a detailed analysis of the arcs reveals the presence of a grains and grains boundary. 